\title{
Do employees' generational cohorts influence corporate venturing? A multilevel analysis
}

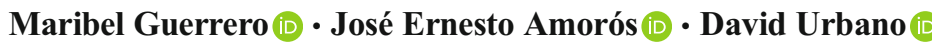

Accepted: 18 November 2019 / Published online: 18 December 2019

(C) The Author(s) 2020

\begin{abstract}
Organizations are facing an interesting phenomenon in the composition of their workforce: the concurrence of multiple age generations that demand suitable strategies regarding work design, job satisfaction, and incentives. Ongoing entrepreneurship and strategic management debates require a better understanding of the relationship between workplace generational cohorts' configurations and organizational performance. We propose a conceptual model for understanding how a diversified workforce influences some determinants (i.e., employees' human capital and attitudes, organizational climate, and environmental conditions) of entrepreneurial organizations' outcomes (i.e.,
\end{abstract}

M. Guerrero · J. E. Amorós

School of Business and Economics, Universidad del Desarrollo, Av. Plaza 680, San Carlos de Apoquindo, Santiago, Chile

M. Guerrero $(\bowtie)$

Newcastle Business School. Northumbria University, 2 Ellison Pl, Newcastle upon Tyne, United Kingdom

e-mail: maribel.guerrero@northumbria.ac.uk

J. E. Amorós

EGADE Business School, Tecnológico de Monterrey, Ave. Carlos Lazo 100, Santa Fe, 01389 Ciudad de México, Mexico

D. Urbano

Department of Business, School of Economics and Business, Universitat Autònoma de Barcelona. Cerdanyola del Vallés, Barcelona, Spain

D. Urbano

Centre for Entrepreneurship and Social Innovation Research (CREIS), Universitat Autònoma de Barcelona. Cerdanyola del Vallés, Barcelona, Spain corporate venturing). Our framework offers insights into corporate venturing determinants for three generational cohorts: Baby Boomers, Generation X, and Generation Y. Using a sample of 20,256 employees across 28 countries, our findings lend support to the positive effect of individual and organizational determinants on corporate venturing, as well as how these effects are reinforced per generational cohort. Specifically, our results show that younger generations (millennials) have more propensity to be involved in corporate venturing activities. This study also contributes to thoughtprovoking implications for entrepreneurial organizational leaders who manage employees from different generations.

Keywords Human capital · Organizational design · Environmental conditions · Entrepreneurship · Corporate venturing $\cdot$ Generational cohorts · GEM

JEL Classifications J24 $\cdot$ M14 $\cdot$ Q5 $\cdot$ L26 $\cdot$ M13 $\cdot$ R23

\section{Introduction}

Many organizations around the world are dealing with the irrevocable effect of the heterogeneous composition of their labor force. This phenomenon is strongly related with one of workforce's composition dynamics: the presence of multiple generations in workplaces given the increasing longevity of the population (King and Bryant 2017; Kooij et al. 2011; Bloom and Van Reenen 2010). While there is no consensus in the 
literature regarding the definitions of the different generations (Stewart et al. 2017), current workplaces are composed of least three generations: Baby Boomers (born 1944-1964), Generation X (born 1965-1980), and Generation $Y$ (born 1981-1995)—well known as Millennials. To add to this complexity, the "youngest" members of the post-millennial generation (born after 1996), or Generation Z, have recently started to be active members in the labor force.

The generational composition has relevant socioeconomic and sociodemographic implications that definitively shape management disciplines. For example, generational cohorts have been crucial for understanding consumer patterns in marketing research (Müller and Neck 2010). From an organizational perspective, the labor force composition represents a challenge that needs to be understood to define adequate strategies regarding work design, incentives/satisfaction, and organizational performance (European Commission 2012; Stewart et al. 2017; Stone and Deadrick 2015; von Bonsdorff et al. 2018). From an entrepreneurship perspective, ongoing academic debates regarding age and entrepreneurship have centered on the literature exploring individuals' occupational choices. The majority of these studies have shown how the identification of entrepreneurial opportunities and intentions increases/decreases with age (Zhang and Acs 2018). However, the entrepreneurship field is not only related to the creation of start-ups and new independent businesses; entrepreneurship can also manifest in large and established organizations and can be performed by employees (Narayanan et al. 2009). Therefore, there are still unexplored insights regarding the influence of employees' age (or generational cohort) on organizational entrepreneurship/ innovation strategies as well as the effects of this influence on performance (Burton et al. 2016a, 2016b). The research agenda on age and entrepreneurship at the organizational level demands multidisciplinary conceptual and methodological approaches to understand the significant effect of age on entrepreneurial organizations (Kuratko et al. 2015; von Bonsdorff et al. 2018). Some examples include the necessity to analyze organizational design (e.g., definition of tasks/roles based on capabilities/attitudes), organizational human resource management (e.g., incentive pay, satisfaction, and career promotion), and organizational performance (Bloom et al. 2014; De Meulenaere et al. 2016; von Bonsdorff et al. 2018).

Inspired by these academic debates, this paper aims to understand how some determinants (i.e., employees' human capital and attitudes, organizational climate, and environmental economics conditions) of entrepreneurial organizations' outcomes (i.e., corporate venturing) are influenced by a diversified workforce-related with their generational cohorts. We analyzed the most representative generational cohorts in the current workplace: Baby Boomers, Generation $X$, and Generation Y/Millennials. Using a sample of 20,256 employees across 28 countries; our results provide insights into the statistically significant and positive effect of diversified human capital and favorable attitudes toward entrepreneurship in the employees' likelihood of participating in corporate venturing initiatives. Our findings show the moderation role of generational cohorts reinforcing the positive effect of individual determinants (human capital and attitudes toward entrepreneurship) and organizational determinants (autonomy, meaningful job, and rewards) of corporate venturing. In particular, our findings show a positive and significant effect of the interaction of the youngest generation of employees (GenY/Millennials) with the highest propensity of being intrapreneurs in their workplaces, in contrast to the oldest generations of employees (Gen Xers and Baby Boomers).

Our paper has three contributions for this ongoing and recent academic debate: (1) reinforcing the academic debate about the effect of human capital and attitudes toward entrepreneurship on corporate venturing for the different generational cohorts (Twenge 2010; Costanza et al. 2012; Burton et al. 2016b; Lyons et al. 2012; Engel et al. 2017); (2) the discussion about the significant influence of autonomy, meaningful job, and rewards on corporate venturing for the different generational cohorts (James et al. 2011; Rigtering and Weitzel 2013; Lyons and Kuron 2014; King and Bryant 2017); and (3) extending the debate about the influence of environmental conditions on corporate venturing strategies according to the perceptions of the different generational cohorts (Twenge et al. 2010; Colombo et al. 2016a; Shane 2011; Wright and Hitt 2017).

The remainder of this paper is organized as follows: Conceptual framework develops the conceptual framework. Methodology presents the methodology used in 
the study. Findings and discussion discusses the main findings. Finally, Conclusions presents the main conclusions, implications for decision-makers, and future lines of research.

\section{Conceptual framework}

2.1 Corporate venturing and employees' generational cohorts

The phenomenon of "entrepreneurship within existing organizations," or "corporate entrepreneurship," is understood as the entrepreneurial behavior of an individual or group of individuals inside an established organization who create corporate ventures or initiate renewal/ innovation strategies in the organization (Morris, Kuratko and Covin, 2011; Sharma and Chrisman 1999). Within this perspective, corporate entrepreneurship includes two entrepreneurial phenomena (Guth and Ginsberg 1990; Sharma and Chrisman 1999): corporate venturing linked to the creation of new business units or spinoffs and strategic entrepreneurship linked to strategic renewal.

In this study, we analyze the influence of generational cohorts on corporate venturing processes. According to Sharma and Chrisman (1999, p. 19), corporate venturing represents corporate entrepreneurial efforts to create new ventures within an organization. In this definition, parent organizations harness implies internal/external means to create new business models via corporate ventures that may or not be related to their core business (Narayanan et al. 2009; Antoncic and Antoncic 2011; Hornsby et al. 2013; Srivastava and Agrawal 2010). Moreover, corporate ventures include several strategies and practices for pursuing business opportunities across all levels of the organization. There is a consensus that there are three critical components behind any corporate venturing strategy: (1) the workforce (i.e., employees) that executes the strategy using their knowledge/skills influenced by their motivations/behaviors; (2) favorable organizational conditions (e.g., culture and reward systems) that support the implementation of this strategy; and (3) external conditions, such as technology, society, and economic markets that enhance/diminish the development of corporate venture projects (Ireland et al. 2009; Kuratko et al. 2015; Narayanan et al. 2009; Titus Jr. et al. 2017).

Given the complexity of understanding the specific effects of generational cohorts into entrepreneurial activities, we identify three theoretical approaches that help us to understand the differences per generation and their connection with the determinants of corporate venturing. First, paying attention to the individual, the human capital theory literature explains how the accumulation, performance, and productivity of human capital (knowledge, experiences, and abilities) vary per generations (Becker 1964; Rosenzweig 1990; Becker 2002; Prskawetz et al. 2008). Empirical studies have shown the timeline in the accumulation-performance of human capital: the rise in the first 10 years of working life, the maxes out around 30-35 years old, the stability around 40 years old, and the decline after 50 years old (Becker 2002; Simpson et al. 2002). The nature of the accumulated human capital varies with the advances in knowledge/technology observed in each generation to become the determinant of youth/senior entrepreneurs (Awogbenle and Iwuamadi 2010; Pilkova et al. 2014). Therefore, the accumulation of specific human capital associated with favorable attitudes toward entrepreneurship are the elements that define individuals' career choices (Dunn and Holtz-Eakin 2000; Douglas and Shepherd 2002; Levesque and Minniti 2006). Second, paying attention to workplaces, the sociological approach provides theoretical bases to explain the differences in work values per generational cohorts. In this regard, generational differences are defined by the complex combination of experiences, the collective culture, and the competition for resources that shared a group of individuals. This combination of elements produced an impact on the values and motivations of this group of individuals that are observed within the workplace and other activities of life (Parry and Urwin 2011). In this regard, employees born between specific dates can exhibit a particular set of work values and attributes associated with their expected levels of autonomy, satisfaction, and rewards. As a consequence, managers may detect the differences in work values or preferences per generation in the strategic design of jobs/tasks. Third, paying attention to environmental conditions, the institutional theory helps to explain the socioeconomic differences per generational cohorts that influence corporate venturing. Institutions represent the invisible rules of the game that affects individual and organizational behaviors (Scott, 1987, 2013; North 1990). Each generational cohort has a shared collective memory (historical events and experiences) that is maintained among peers and drives their values, behaviors, and social identities (Hung et al. 2007; Micelotta et al. 
2017; Yusoff et al. 2019). Although generational differences are not only attributable to an individual's age, these theoretical approaches that provide some particularities of each generation's shared experiences, attitudes, and behaviors could influence their human capital and attitudes toward entrepreneurship (Chen and Choi 2008; Cennamoand Gardner, 2008; Gibson et al. 2009; Parry and Urwin 2011; Costanza et al. 2012). In the next section, we describe some of the determinants that influence corporate venturing among the different generational cohorts and establish hypotheses to test these determinants and the moderating role of the cohorts.

\subsection{Hypotheses}

\subsubsection{Employee-related determinants of corporate venturing and the influence of generational cohorts}

In general, human capital is a determinant in the propensity to engage in entrepreneurial activities (Dunn and Holtz-Eakin 2000; Parker 2011). Employees' human capital represents a core competence for entrepreneurial organizations (Becker 1964; Fuller et al. 2006; Alpkan et al. 2010; Millan et al. 2014). Pursuing entrepreneurial and innovative opportunities requires human capital from diversified/qualified employees (Ireland et al. 2009; Knudsen and Lien 2015). Extant studies have shown that human capital has a positive impact on corporate venturing (Parker 2011; Guerrero and Peña-Legazkue 2013; Guerrero and Peña-Legazkue 2014). More specifically, research has shown that employees with higher education are more proactive in solving "problems" due to their curiosity (Hayton 2005; Bosma et al. 2010; Millan et al. 2014). In addition, employees with prior entrepreneurial, investor, and managerial experience are the main determinants to business opportunities in uncertain, risky, and challenging scenarios (Ucbasaran et al. 2009; Bosma 2013; Alrumaithi et al. 2015).

The entrepreneurship literature on youth and senior entrepreneurship has also provided relevant insights regarding the influence of age on the link between human capital and entrepreneurial activities (Levesque and Minniti 2006; Awogbenle and Iwuamadi 2010; Pilkova et al. 2014). Specific to corporate venturing, the link between employees' human capital and corporate venturing activities are influenced by the aging perspective (Stevens 2010; Wanberg et al. 2016; Garrett et al. 2017; Stewart et al. 2017). According to this perspective, Baby Boomers are excellent mentors
(Smola and Sutton 2002; Wong et al. 2008) given their strong experience in leadership positions (Gibson et al. 2009; Rodriguez et al. 2003; Yu and Miller 2005) and technical knowledge (Cennamo and Gardner 2008). Gen Xers also tend to be passionate mentors (Smola and Sutton 2002) given their technical competence and updated knowledge based on life-long learning (Cennamo and Gardner 2008). Gen Yers live in a digital world and are "connected" $24 \mathrm{~h}$ a day via cell phones, tablets, and computers (Smola and Sutton 2002; Wong et al. 2008), college studies (Cennamo and Gardner 2008), and a digital learning orientation (Gibson et al. 2009). Each generational cohort likely contributes strong capabilities and expertise during the execution of corporate venturing activities. Assuming certain particularities for each generational cohort, we believe that employees' generation could influence how their human capital affects corporate venturing. In this regard, we suggest the following hypotheses:

Hypothesis 1: Employees with diversified human capital are more prone to participate in corporate venturing activities than employees without diversified human capital.

Hypothesis 1a: Youngest generational cohorts positively moderate the effect of employees' diversified human capital on corporate venturing activities.

Employees' attitudes toward entrepreneurship are mental representations of personal and/or environmental characteristics (Liñán et al. 2011a, 2011b) that shape their entrepreneurial abilities/skills, self-efficacy, role models perceptions, and risk aversion (Ireland et al. 2009; Khedhaouria et al. 2015). Employees who are more confident in their ability to start a venture are more likely to participate in corporate venture activities than employees who do not feel confident in their entrepreneurial abilities/skills (Guerrero and Peña-Legazkue 2013). Entrepreneurial employees' confidence also increases/decreases based on their perceptions of role models inside/outside the workplace who demonstrate the feasibility of corporate venture activities (Van Auken et al. 2006). Another relevant entrepreneurial attitude is associated with employees' perceptions of risk and failure (Simon et al. 2000). In this regard, when employees perceive business opportunities as achievable, they are more likely to engage in corporate venturing activities promoted by their employers (Guerrero and PeñaLegazkue 2014). 
Assuming that employees' attitudes toward entrepreneurship are a relevant determinant of corporate venturing, the moderation effect of generational cohorts on employees' attitudes toward corporate venturing plays an important role. For example, Baby Boomers are known to take risks, be competitive (Gibson et al. 2009), and embrace change (Smola and Sutton 2002). Similar to Baby Boomers and influenced by worldwide competition (Smola and Sutton 2002), Gen Xers are also willing to take risks but with certain limitations because they saw how their parents' companies were downsized (Eisner 2005). Moreover, Gen Xers tend to be more creative and self-sufficient (Gibson et al. 2009), and they often put forth the effort to become (intra) entrepreneurs because it is an attractive career path for them. On the other hand, Gen Yers typically value skill development, enjoy the challenge of new opportunities and innovations, and display high levels of confidence (Wong et al. 2008). Gen Yers also tend to be serial entrepreneurs due to their entrepreneurial spirit, answer-seeking behavior, personal responsibility, need for faster feedback, and focus on outcomes (Gibson et al. 2009). Based on these generational characteristics, Gen Yers' attitudes are likely more entrepreneurial than those of Gen Xers and Baby Boomers due to their Gen Yers' tendency to be creative, innovative, risk-taking, ambitious, and freedom-seeking (Müller and Neck 2010). Assuming that employees' attitudes are associated with the main components of any corporate venturing activity, we suggest the following hypotheses:

Hypothesis 2a: Youngest generational cohorts positively moderate the effect of employees' positive attitudes toward entrepreneurship on corporate venturing activities.

\subsubsection{Organizational determinants of corporate venturing and the influence of generational cohorts}

By nature, the organizational design/climate is a key determinant of corporate venturing activities (Colombo et al. 2016b). More concretely, organizational support (working time, work conditions/design, rewards systems, culture, and job security) and organizational values (loyalty, commitment, recognition, involvement, and motivation) are driving forces of employees' satisfaction and predictors of entrepreneurial opportunities (Grégoire et al. 2010; Antoncic and Antoncic 2011).
Previous studies have demonstrated positive relationships between organizational determinants and employees' involvement in corporate venturing activities (Antoncic and Hisrich 2001; Ireland et al. 2009; Narayanan et al. 2009). For example, Kuratko et al. (2005a, 2005b) identified that autonomy, a meaningful job, and rewards foster employees' corporate venturing activities. An effective intrapreneurial orientation among employees involves autonomy to perform their jobs and explore opportunities (Hornsby et al. 2002; Alpkan et al. 2010; Bindl and Parker 2010), a meaningful job in relation to their value systems and personal goals (Dose 1997; Liden et al. 2000; Amabile and Kramer 2011; Fairlie 2011), and reward systems (Hornsby et al. 2002; Fehr and Schmidt 2007; Alpkan et al. 2010; Monsen et al. 2010; Bloom et al. 2014).

Employees' perceptions of these three organizational determinants of corporate venturing are likely to vary across the generational cohorts. For example, Baby Boomers are the largest generational cohort in the workforce and characterized by traditional work values. For example, they have strong company loyalty and commitment; are hardworking; look for job security and a stable working environment; develop good relationships with supervisors and co-workers, and value success, teamwork, inclusion, and rule challenging (Chen and Choi 2008; Gibson et al. 2009; Smola and Sutton 2002; Wong et al. 2008). Therefore, Baby Boomers have difficulty balancing their work and family lives. In this regard, Baby Boomers often find organizational climate with autonomy and economic rewards as the most favorable. In contrast, Gen Xers often do not to display loyalty to a particular organization because they tend to be more independent and self-sufficient than previous generations (Cennamo and Gardner 2008; Parry and Urwin 2011; Wong et al. 2008). In this sense, Gen Xers are more likely to leave a job and seek out more challenging options, a higher salary, improved benefits, and immediate and continuous feedback (Gibson et al. 2009). Moreover, Gen Xers are more committed to their personal goals than to organizational goals. Therefore, Gen Xers perceive a favorable climate based on meaningful job and rewards. Gen Yers crave higher salaries, flexible work arrangements, and more financial leverage (Gibson et al. 2009; Smola and Sutton 2002; Wong et al. 2008). Furthermore, Gen Yers have a tremendous appetite for work and high levels of confidence and are socially active, comfortable with change, and less likely to see job security as a significant factor in the 
workplace. Consequently, Gen Yers often find organizational climates characterized by a meaningful job as the most favorable. Assuming the influence of employees' age on their perceptions of organizational determinants of corporate venturing, we suggest the following hypotheses:

Hypothesis 3: Employees with favorable perceptions of their organizational climate are more prone to participate in corporate venturing activities than employees without these perceptions.

Hypothesis 3a: Youngest generational cohorts positively moderate the effect of employees' favorable perceptions of their organizational climate on corporate venturing activities.

\subsubsection{Environmental determinants of corporate venturing and the influence of generational cohorts}

Previous studies have shown that environmental conditions (e.g., social, cultural, economic, technological, and political) are relevant determinants of any entrepreneurial activity (Gnyawali and Fogel 1994; Parker 2012). In corporate entrepreneurship, external or environmental conditions determine the identification of business opportunities and explain of the success/failure of corporate entrepreneurship strategies (Shepherd et al. 2017; Shepherd and Patzelt 2017; Titus et al. 2017). According to Ireland et al. (2009), Narayanan et al. (2009), and Bosma et al. (2010 and 2011), corporate venturing is often a logical response to the presence of environmental conditions like competitive intensity, technological change, innovation change (from an organizational vision), and labor market conditions (from an employee vision).

First, competitive intensity is often associated with relative parity among organizations competing within an industry (Porter 1980). To break out of parity, organizations must explore and exploit some basis for competitive advantage (Ireland et al. 2009). Therefore, organizations could pivot into an entrepreneurial innovation that allows them to use resources/capabilities to be competitive on distinct and valued bases (Autio et al. 2014). Second, technological dynamism represents a source of corporate venturing opportunities, particularly for organizations with technology-based competitive advantages (Parker 2011). Prior studies have shown that industries with high levels of R\&D intensity characteristically exhibit technological dynamism that could be a source of corporate venturing activities (Titus et al., 2017). Third, according to Sahaym et al. (2010), frequent changes in $\mathrm{R} \& \mathrm{D}$ exert pressure on incumbent organizations to actively innovate, explore opportunities, and assume risks associated with exploiting current knowledge rather than seeking new knowledge. In contrast, in stable innovation environments, organizations tend to predict and efficiently manage their R\&D activities due to a lack of pressure. Fourth, labor market conditions have a substantial effect on the career decision of employed, self-employed, and unemployed individuals. For instance, the entrepreneurship literature has shown that higher unemployment rates negatively affect the individuals' perceptions of available opportunities as well as their entrepreneurial actions (Koellinger and Thurik 2012; Hastie 2001). In uncertain labor markets (e.g., higher levels of unemployment), entrepreneurs behave entrepreneurially in response to their personal and professional expectations (McMullen and Shepherd 2006). Concerning generational cohorts, Constanza et al. (2012) argued that each generation tends to be influenced by similar environmental conditions experienced by individuals throughout their lifecycle (childhood, adolescence, and adulthood). The events each generation experiences impact their behaviors, actions, and values related to work and entrepreneurship.

Following these arguments, each generation's experiences also shape the way they face and react to their current organizational landscape (e.g., competitive intensity, technological and innovation change, and labor market conditions). For instance, Baby Boomers grew up embracing the psychology of entitlement and expecting the best from life because they were profoundly affected by several social, economic, and political events (Gibson et al. 2009; Wong et al. 2008). As a result, Baby Boomers are hardworking and loyal, they seek job security and recognition, and they tend to challenge rules (Yu and Miller 2005). In the current organizational landscape, Baby Boomers could be afraid that uncertainty in the labor market could affect their job security or retirement conditions. Gen Xers grew up with (financial, family, and societal) insecurity, rapid changes, diversity, a lack of solid traditions, intense worldwide competition, and (corporate and government) scandals, and they generally distrust institutions (Cennamo and Gardner 2008; Smola and Sutton). These conditions explain their lack of loyalty and their continued search for empowerment and rewards with an 
entrepreneurial spirit. In the current organizational landscape, Gen Xers adapt to changes and tend to evaluate the costs/benefits of becoming an entrepreneurial employee or self-employed (Yu and Miller 2005). Finally, Gen Yers grew up under economic uncertainty and insecurity (Gibson et al. 2009). They accept diversity and are prone to volunteering. As a result, they are likely to become involved in corporate venturing activities if they identify a balance between organizational purposes and societal objectives in those activities (Kowske et al. 2010). Assuming the influence of employees' age on perceptions of environmental determinants of corporate venturing, we suggest the following hypotheses:

Hypothesis 4: Employees who live in countries with unfavorable environmental conditions are less prone to participate in corporate venturing activities than employees who live in countries with favorable environmental conditions.

Hypothesis 4a: Youngest generational cohorts positively moderate the effect of unfavorable environmental conditions on corporate venturing activities.

\subsection{Proposed conceptual model}

Table 1 summarizes generational trends/patterns associated with the three determinants of corporate venturing strategies discussed in previous studies. We assume that generational cohorts likely influence workplace corporate venturing strategies and outcomes (Lamm and Meeks 2009).

Based on previous arguments, Fig. 1 shows the conceptual model proposed in this paper. In summary, we explore whether human capital (H1), attitudes toward entrepreneurship (H2), organizational determinants (H3), and environmental conditions (H4) have a direct effect on corporate venturing as well as whether generational cohort has a moderating effect on these relationships(H1a, H2a, H3a, and H4a).

\section{Methodology}

\subsection{Data collection}

Our data came from the Global Entrepreneurship Monitor (GEM) project; it is an international research program focused on entrepreneurship that conducts a standardized study in more than 70 countries annually (Reynolds et al. 2005). More specifically, we used data from the 2012 and 2013 Adult Population Survey (APS). ${ }^{1}$ We selected these two survey waves primarily because, during these years, the APS survey included a set of questions that captured information about (1) corporate entrepreneurship activities (e.g., venture creation) and (2) workplace characteristics (e.g., perceptions about a meaningful job, autonomy, and income satisfaction). For us, it was an excellent opportunity to capture information at the individual, organizational, and country levels, thus allowing us to achieve our research objectives. The APS information was complemented with data at the country level from World Bank Open Data. Our final sample consists of 20,256 employees across 28 countries. $^{2}$

\subsection{Description of variables}

Our dependent variable, corporate venturing, is a dichotomous variable that captures when an employee has (not) undertaken entrepreneurial actions in the last 3 years to create a new venture for an employer that is currently operating in the market. Based on our previous definition of corporate venturing (Sharma and Chrisman 1999), we operationalized this variable using three criteria based on the APS survey information (Bosma et al. 2010, 2011; Guerrero and Peña- Legazkue, 2013, 2014; Alrumaithi et al. 2015; Guerrero and Peña-Legazkue 2019). First, we confirmed employees' involvement in developing intrapreneurial activities for their primary employer in the last 3 years (e.g., employees confirmed their participation in corporate entrepreneurship activities implemented by their employer in the last 3 years; entrepreneurial activities included participating in radical/incremental innovation projects, designing new business units, entering into new markets, and exploiting opportunities to create ventures). Second, we confirmed that the employees were currently trying to create a new business/venture for their employer as part of their regular work (e.g., employees confirmed their participation in creating corporate ventures as a part of their daily work in the organization). Third, we confirmed that employees' new ventures were operating in the market for fewer than 42 months as of the

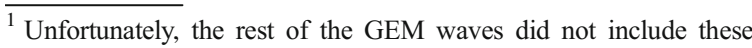
additional questions.

${ }^{2}$ Belgium, Bosnia, Chile, China, Croatia, Denmark, Ecuador, Estonia, Finland, Greece, Hungary, Iran, Korea, Lithuania, Malaysia, Namibia, Nigeria, Peru, Philippines, Poland, Puerto Rico, Romania, Slovakia, Slovenia, United Kingdom, Uruguay, and Vietnam.
} 
Table 1 Determinants of corporate venturing per generational cohort

\begin{tabular}{|c|c|c|c|c|c|}
\hline Dimensions & & Baby Boomers & Gen Xers & Gen Yers & $\begin{array}{l}\text { Theoretical } \\
\text { approaches }\end{array}$ \\
\hline $\begin{array}{l}\text { Employees' } \\
\text { determinants }\end{array}$ & $\begin{array}{l}\text { Attitudes toward } \\
\text { entrepreneurship }\end{array}$ & $\begin{array}{l}* \text { Secondary school or } \\
\text { technical } \\
* \text { Technical training } \\
* \text { Excellent mentors } \\
* \text { Leadership experience } \\
* \text { Competitive } \\
* \text { Embrace change } \\
* \text { Embrace growth }\end{array}$ & $\begin{array}{l}* \text { Secondary school or } \\
\text { undergraduate studies } \\
* \text { Life-long learning } \\
* \text { Crave mentors } \\
* \text { Technical competence } \\
* \text { Entrepreneurial effort } \\
* \text { Creativity } \\
* \text { Self-sufficient }\end{array}$ & $\begin{array}{l}* \text { Undergraduate studies } \\
\text { * Digital learning and } \\
\text { mentors } \\
* \text { Value skill development } \\
* \text { Technology } \\
* \text { Serial entrepreneur } \\
* \text { Curious/ambitious } \\
* \text { Seek challenges, } \\
\text { innovations, and } \\
\text { opportunities } \\
\text { *Economic results oriented }\end{array}$ & $\begin{array}{l}\text { * Human capital: } \\
\text { accumulation, } \\
\text { productivity and } \\
\text { performance } \\
* \text { Career choices } \\
\text { approach }\end{array}$ \\
\hline $\begin{array}{l}\text { Organizational } \\
\text { determinants }\end{array}$ & Work values & $\begin{array}{l}* \text { Workaholic } \\
* \text { Company loyalty } \\
* \text { Individual freedom } \\
* \text { Security oriented } \\
\text { * Rule challenging } \\
* \text { Material satisfaction }\end{array}$ & $\begin{array}{l}* \text { Work/life balance } \\
* \text { Lack of loyalty } \\
* \text { Independent } \\
* \text { Move for career options }\end{array}$ & $\begin{array}{l}* \text { Multi-tasker } \\
* \text { Contract mentality } \\
* \text { Crave feedback } \\
* \text { Change jobs frequently } \\
* \text { Diminished by } \\
\text { dissatisfaction }\end{array}$ & $\begin{array}{l}\text { * Sociological approach } \\
\text { * Organizational } \\
\text { behaviors }\end{array}$ \\
\hline $\begin{array}{l}\text { Environmental } \\
\text { determinants }\end{array}$ & $\begin{array}{l}\text { Conditions } \\
\text { experienced }\end{array}$ & $\begin{array}{l}* \text { Much social change } \\
* \text { Much economic change } \\
* \text { Much political change } \\
* \text { Worldwide openness }\end{array}$ & $\begin{array}{l}* \text { Economic uncertainty } \\
* \text { Insecurity } \\
* \text { Rapid change } \\
* \text { Worldwide competition }\end{array}$ & $\begin{array}{l}\text { * Rapid technological } \\
\text { changes } \\
* \text { Social sensitivity } \\
* \text { Uncertainty and } \\
\text { insecurity } \\
* \text { Digital worldwide }\end{array}$ & $\begin{array}{l}\text { * Institutional theory } \\
\text { * Social identities }\end{array}$ \\
\hline
\end{tabular}

Source: Self-devised based on Benson and Brown 2011; Chen and Choi 2008; Cennamo and Gardner 2008; Gibson et al. 2009; Kupperschmidt, 2000; Smola and Sutton 2002; Hung et al. 2007; Liu et al. 2019; Parry and Urwin 2011; Wong et al. 2008; Zhang and Acs 2018

date of the APS survey (e.g., employees confirmed that the ventures they created were operating in the market during the last 3.5 years; it helps us to indicate the age of their ventures and determine whether the ventures should be classified as new ventures according to the GEM methodology). In summary, our dependent variable,

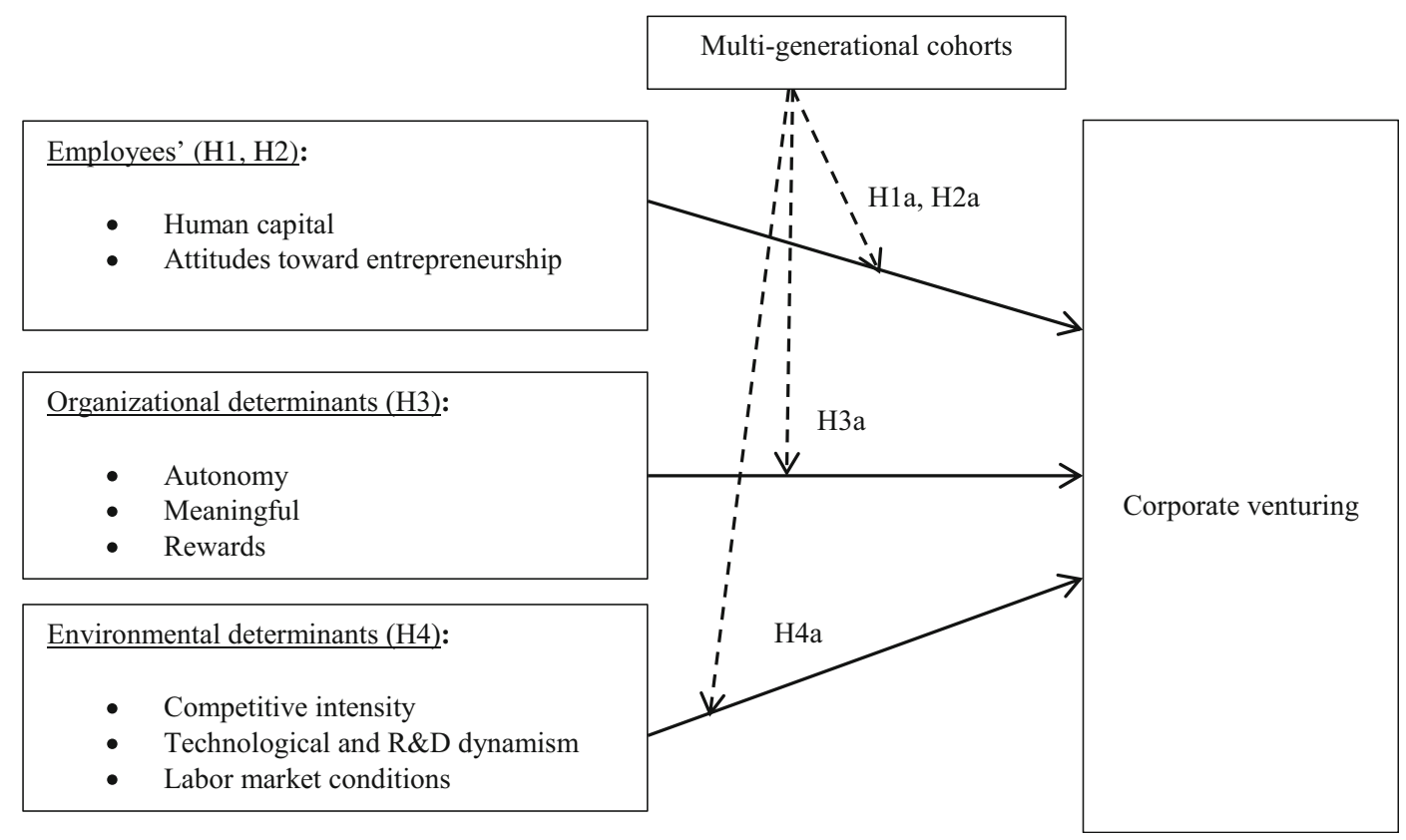

Fig. 1 Proposed conceptual model. Source: Authors 
corporate venturing, takes the value 1 when the employee answered "yes" to the three previous criteria and 0 otherwise.

The first set of explanatory variables, at individual level, captures employees' human capital (Alpkan et al. 2010; Bosma 2013; Parker 2011; Millan et al. 2014; Kuratko et al. 2015), which is composed of a dichotomous variable that takes the value 1 when the employee has a college degree (Higher Education), a dichotomous variable that takes the value 1 when the employee had entrepreneurial experience in the previous year (Entrepreneurial Experience), a dichotomous variable that takes the value 1 when the employee had investor experience in the past 3 years (Investor Experience), and a dichotomous variable that takes the value 1 when the employee had managerial experience (Managerial Experience). The second set of explanatory variables, also at individual level, captures employees' attitudes toward entrepreneurship (Bosma 2013; Guerrero and PeñaLegazkue 2014; Khedhaouria et al. 2015; Simon et al. 2000; Van Auken et al. 2006) and is composed of a dichotomous variable that takes the value 1 when the employee believes he or she has the knowledge, skills, and experience required to start a business (Entrepreneurial Skills); a dichotomous variable that takes the value 1 when the employee believes that fear of failure would prevent him or her from starting a business (Fear of Failure); a dichotomous variable that takes the value 1 when the employee knows someone who has started a business in the past 2 years (Know Entrepreneurs); a dichotomous variable that takes the value 1 when the employee perceives entrepreneurial opportunities in the next 6 months (Opportunity Perceptions); and a dichotomous variable that takes the value 1 when the employee has entrepreneurial intentions (Intentions).

The third set of explanatory variables, are perceptions of the individuals from their organizations, was captured through the additional questions added in the 2012 and 2013 APS survey about employees' perceptions of their work environment (Alrumaithi et al. 2015; Hornsby et al. 2002; Grégoire et al. 2010; Monsen et al. 2010). This set is composed of three workplace environmental characteristics: Meaningful Job, measured with a Likert scale (1= lower to $5=$ higher perceptions that he or she has a meaningful job); Job Autonomy, measured with a Likert scale ( $1=$ lower to $5=$ higher perceptions that he or she can decide how to do his or her work); and Rewards, measured with a Likert scale $(1=$ lower to $5=$ higher perceptions that he or she is satisfied with his or her current income).
The fourth set of explanatory variables, at the country environmental level, measures the economic environment (Ireland et al. 2009; Narayanan et al. 2009; Parker 2011; Sahaym et al. 2010; Titus et al., 2017) and is composed of Competitive Intensity, measured as the natural logarithm of the industry value added per country; Technological Intensity, measured as the natural logarithm of high-technology manufactured exports per country; Innovation Intensity, measured as the natural logarithm of R\&D expenditure per country; and Labor Market Conditions, measured as the natural logarithm of total unemployment per country.

The generational effect was measured with the variable Multi-Generations (Lamm and Meeks 2009). This variable is a categorical variable estimated by the employees' age $^{3}$ : the value 1 for Generation Y (born after 1980), the value 2 for Generation X (born 1965-1980), and the value 3 for Baby Boomers (born 1946-1964).

Finally, a set of control variables was added to our model. At individual level, based on previous GEM studies (Bosma 2013), we included the employees' age measured by the number of years since the date of born; the employees' gender measured by a dichotomous variable that takes the value 1 when the employee reported a male gender; and the employees' income measured by a dichotomous variable that takes the value 1 when the employee reported personal income higher than 68,000 dollars/year. At the organizational level, based on previous GEM studies (Burton et al. 2016a, 2016b), we included variables reported by the employees in the data collection. Concretely, two dichotomous variables collected the employees' roles assumed during corporate venturing activities: leading role in the development of (role 1_development) and/ or leading role in the implementation (role 2 implementation). Employees also reported the size of their employers' organizations in terms of the number of employees that was included in our analysis as a natural logarithm (InSize) and the employers' type expressed by a dichotomous variable that takes value 1 when the organization was private, otherwise if it was public (Orgatype Private).

\footnotetext{
${ }^{3}$ The GEM methodology ensured a representative sample of the adult population in each country in terms of age and gender distribution (for further details, see Reynolds et al. 2005). Therefore, the samples for each country are representative of the adult population and cover our generational cohorts. Moreover, regarding the employees' sample representativeness, employees were the focus of attention during the datacollection process in the analyzed GEM waves.
} 


\subsection{Statistical model}

Our dataset captured information at the employee level (Level 1) and country level (Level 2). With this data, it is possible to implement multilevel moderation effects (Guo and Zhao 2000; Elam 2014). Using Stata software, we conducted a multilevel analysis for the binary variables: we used melogit procedure to capture coefficients and meologit to capture odds ratios (StataCorp 2013). We show our results via odds ratios because it is a single summary score of the effect, and the probabilities are more intuitive than simple coefficients (see Madanoglu et al. 2019; Mickiewicz et al. 2019). The odds demonstrate the probability that an outcome (e.g., corporate venturing) will occur in the presence of a given variable (e.g., each of the determinants included in our analysis). For interpretation, an odds ratio value lower than 1 indicates a negative coefficient, and an odds ratio value greater than or equal to 1 indicates a positive coefficient (Langer 2017). The correlation matrix reveals that most of the explanatory variables are not highly correlated (Table 2). The mean variance inflation factor (VIF) is 1.82 , indicating that the entire model is moderately correlated. ${ }^{4}$ However, as we expected, age ${ }^{5}$ and generational cohort are the most highly correlated variables in this analysis.

To test our hypotheses, we first ran a general model with the entire sample (Model 1) and per generational cohort (Models 1a, 1b, and 1c). To test the moderation effect of the generational cohorts, we then built an interaction among the determinant variables to reduce the complexity in the analysis of each dimension. Afterwards, we created interactions between each determinant of corporate venturing and each generational cohort. We then tested this new mixed-effect logistic model with the entire sample (Model 2), and the interactions are shown per determinant dimension (Models 2a, $2 \mathrm{~b}, 2 \mathrm{c}$, and $2 \mathrm{~d})$.

\footnotetext{
${ }^{4}$ A rule of thumb is that if VIF $>10$ then multicollinearity is high. The cutoff of 5 is also commonly used to denote moderate correlation among independent variables (Aiken et al. 1991).

${ }^{5}$ The square term of age (Age2) presents multicollinearity. For this reason, we decide to omit this variable in the analyses (Allen 1997). We discuss this limitation in the conclusions.
}

\section{Findings and discussion}

\subsection{Descriptive statistics}

Table 3 shows the descriptive statistics for the entire sample as well as for each generational cohort. Across 28 countries $^{6}$, the prevalence of having created a corporate venture in the last 3 years is approximately $11 \%$. With regard to human capital, on average, 29\% have higher education as well as diversified prior experience, including managerial (12\%), entrepreneurial (3\%), and investor $(6 \%)$ experience. The results also reveal that $25 \%$ of employees in the sample intend to create their own business in the next 3 years, 39\% of them know entrepreneurs, $35 \%$ of them perceive business opportunities, $49 \%$ of them believe they have entrepreneurial skills, and $44 \%$ of the sample express has a fear of failure. In addition, employees have positive perceptions of their workplaces (three on a five-point Likert scale). The descriptive statistics also show the prevalence of corporate venturing activities per generational cohort. In contrast with their predecessors (Gen Xers and Baby Boomers), Gen Y employees have relevant participation in corporate venturing activities $(12 \%$ vs. $9 \%$ and $6 \%$, respectively), which was statistically supported ${ }^{7}$. Furthermore, Gen Y employees show more favorable attitudes toward entrepreneurship than their predecessors: $32 \%$ have intentions to start a business, $44 \%$ have entrepreneurial role models, $43 \%$ have opportunity perceptions, $51 \%$ believe they have entrepreneurial skills, and $39 \%$ have a fear of failure. Interestingly, there are no substantial differences among generations in their evaluations of their organizational climate. Moreover, $31 \%$ of Baby Boomers have assumed leading roles in the development of corporate venturing ideas respect to $10 \%$ of Gen $\mathrm{X}$ and $\mathrm{Y}$ employees.

\footnotetext{
${ }^{6}$ Appendix 1 shows the employees' distribution of our sample per country. In particular, we identify similar patterns. There is a concentration of Baby Boomers in the United Kingdom (15\%) as well as developing economies such as Namibia (6\%), Iran (6\%) and Chile (5\%). We also observed a concentration of Gen Xers in the United Kingdom (14\%) and China (7\%). Also, Gen Yers have a presence in central European countries such as Slovakia (7\%), Slovenia (7\%), Lithuania (7\%) and Hungary (6\%).

${ }^{7}$ Our t-test shows that Gen Yers [0.12; $\left.p=0.001\right]$ have more propensity to be involved in corporate venturing activities than Baby Boomer [0.062; $p=0.002]$ and Gen Xers $[0.091 ; p=0.001]$. The $p$ value for the difference between different generations is less than 0.05 , so we conclude that the difference in means is statistically significantly different from 0 (based on a two-tailed significance level).
} 


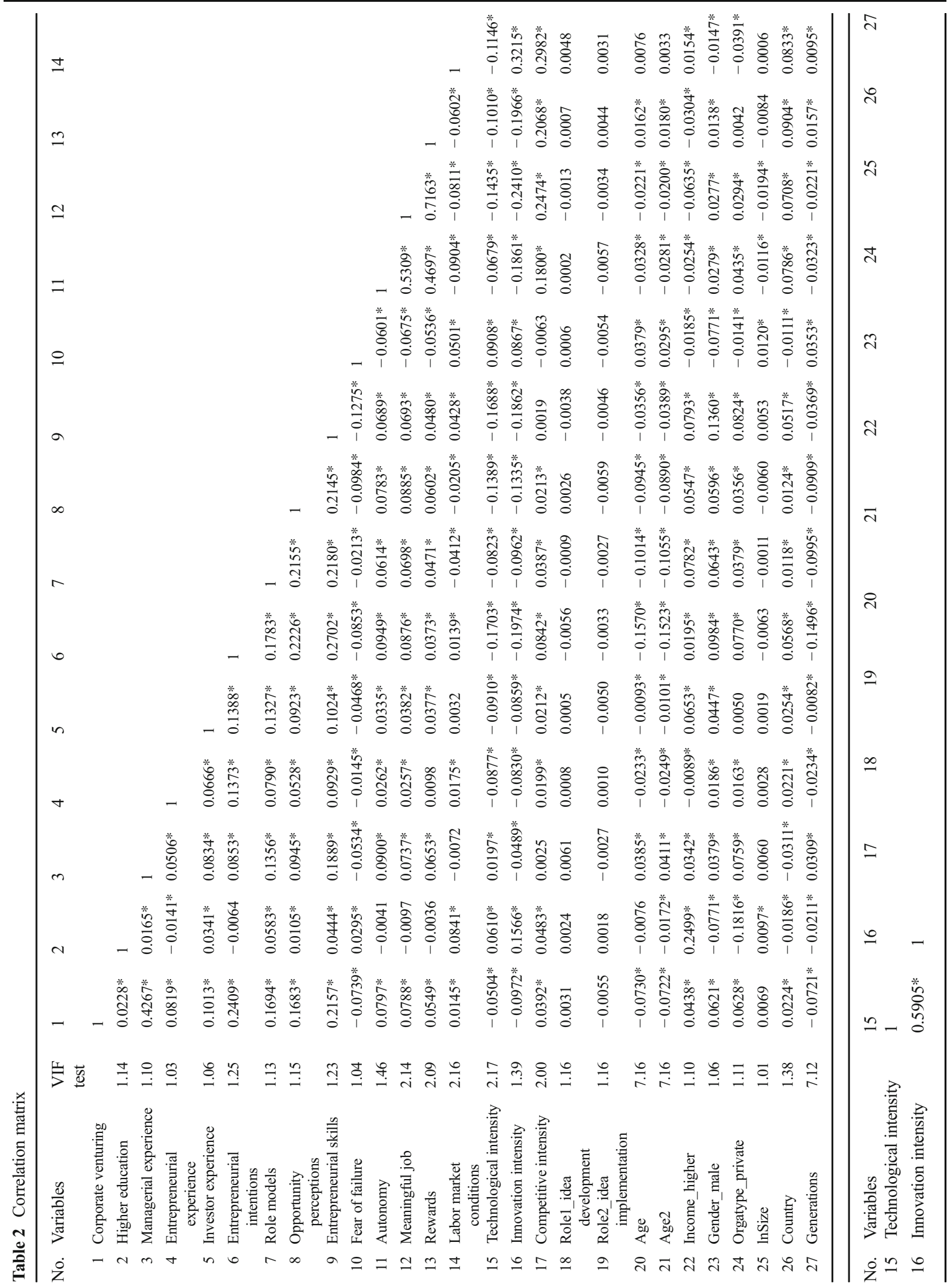




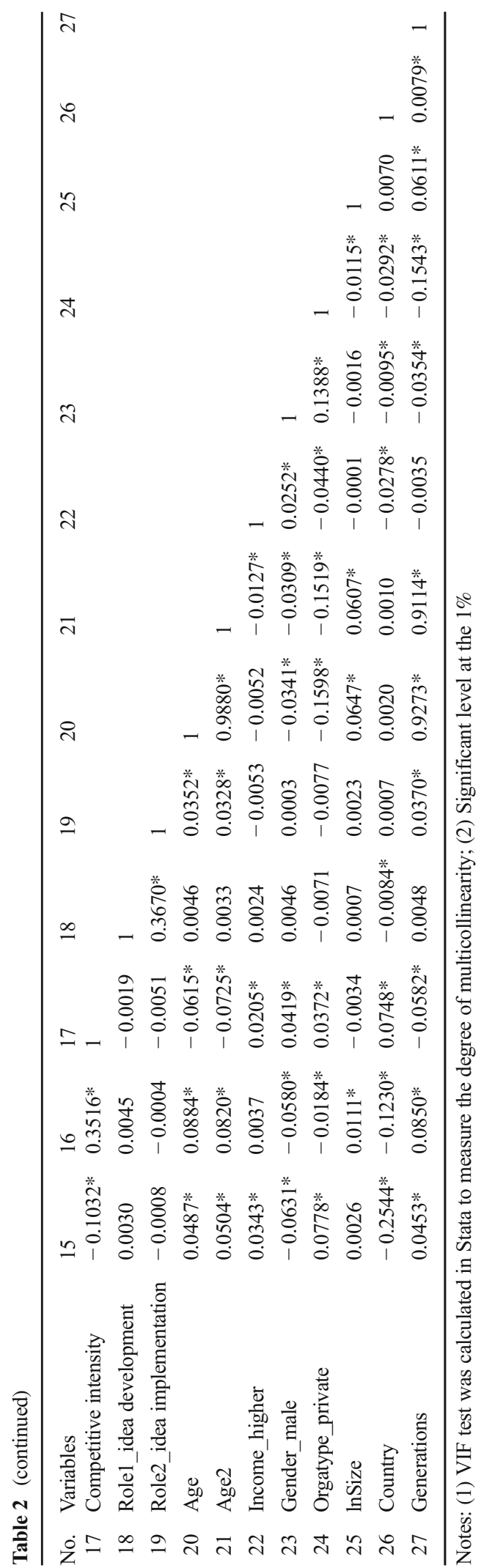

4.2 Determinants of corporate venturing activities

The results in Table 4 show the directional probability (e.g., increasing or decreasing probability of corporate venturing) for human capital, organizational climate, and environmental conditions (Model 1). Taking the Baby Boomers as a reference, the results show differences in Baby Boomers' propensity to be involved in corporate venturing initiatives compared with Gen Yers $(1.380 ; p<0.100)$ and Gen Xers $(1.282 ; p<0.050)$. Contrary to previous studies that have studied the relationship between types of entrepreneurship and age (Bönte et al. 2009; Zhang and Acs 2018), our findings show how the probability of being engaged in corporate venturing activities decreases with the level of maturity of the generational cohort.

With regard to employee determinants, we observe interesting patterns for human capital and attitudes toward entrepreneurship. Exploring human capital, we found that managerial experience $(1.535 ; p<0.010)$, entrepreneurial experience $(1.351 ; p<0.100)$, investor experience $(1.325 ; p<0.010)$, and higher education $(1.197 ; p<0.010)$ increase the probability that an employee will be engaged in corporate venturing activities (supporting H1). These findings suggest that human capital from a diversified and qualified workforce represents a core competence for entrepreneurial organizations (Alpkan et al. 2010; Millan et al. 2014) and the role of human capital such as an antecedent of corporate venturing activities (Parker 2011; Guerrero and PeñaLegazkue 2013; Guerrero and Peña-Legazkue 2014). The analysis of human capital per generation (Models $1 \mathrm{a}, 1 \mathrm{~b}$, and 1c) shows that, in contrast to their predecessors (Baby Boomers and Gen Xers), Gen Yers' participation in corporate venturing activities is influenced by their higher education $(1.270 ; p<0.050)$, managerial experience $(1.672 ; p<0.010)$, and previous entrepreneurial experience $(1.536 ; p<0.050)$. Interestingly, investor experience increases the probability that Gen Xers engage in corporate venturing activities by approximately 1.5 times $(1.547 ; p<0.050)$. Similarly, managerial experience increases Baby Boomers' likelihood of engaging in corporate venturing activities by approximately 1.6 times $(1.674 ; p<0.010)$. These results are in line with prior studies that have adopted a multigenerational perspective (Stevens 2010; Stewart et al. 2017) and have shown the main characteristics per generation in terms of human capital, such as Baby Boomers' strong leadership ability (Gibson et al. 2009; 
Table 3 Descriptive statistics

\begin{tabular}{|c|c|c|c|c|c|c|c|c|}
\hline \multirow[t]{2}{*}{ Variable } & \multicolumn{4}{|c|}{$\begin{array}{l}\text { All Generations } \\
{[20,256 \text { employees }]}\end{array}$} & \multicolumn{4}{|c|}{$\begin{array}{l}\text { Gen Yers } \\
\text { [6821 employees] }\end{array}$} \\
\hline & Mean & Std. Dev. & Min & Max & Mean & Std. Dev. & Min & Max \\
\hline Corporate venturing & 0.11 & 0.02 & 0.00 & 1.00 & 0.12 & 0.32 & 0.00 & 1.00 \\
\hline Higher education & 0.29 & 0.01 & 0.00 & 1.00 & 0.31 & 0.46 & 0.00 & 1.00 \\
\hline Managerial experience & 0.12 & 0.00 & 0.00 & 1.00 & 0.10 & 0.30 & 0.00 & 1.00 \\
\hline Entrepreneurial experience & 0.03 & 0.00 & 0.00 & 1.00 & 0.03 & 0.18 & 0.00 & 1.00 \\
\hline Investor experience & 0.06 & 0.00 & 0.00 & 1.00 & 0.06 & 0.24 & 0.00 & 1.00 \\
\hline Entrepreneurial intentions & 0.25 & 0.05 & 0.00 & 1.00 & 0.32 & 0.47 & 0.00 & 1.00 \\
\hline Role models & 0.39 & 0.03 & 0.00 & 1.00 & 0.44 & 0.50 & 0.00 & 1.00 \\
\hline Opportunity perceptions & 0.35 & 0.03 & 0.00 & 1.00 & 0.43 & 0.50 & 0.00 & 1.00 \\
\hline Entrepreneurial skills & 0.49 & 0.01 & 0.00 & 1.00 & 0.51 & 0.50 & 0.00 & 1.00 \\
\hline Fear of failure & 0.44 & 0.02 & 0.00 & 1.00 & 0.39 & 0.49 & 0.00 & 1.00 \\
\hline Autonomy & 3.29 & 0.04 & 1.00 & 5.00 & 3.32 & 1.38 & 1.00 & 5.00 \\
\hline Meaningful job & 3.31 & 0.02 & 1.00 & 5.00 & 3.32 & 1.50 & 1.00 & 5.00 \\
\hline Rewards & 3.23 & 0.01 & 1.00 & 5.00 & 3.18 & 1.35 & 1.00 & 5.00 \\
\hline Labor market conditions & 2.17 & 0.01 & 1.13 & 4.19 & 2.23 & 0.73 & 1.13 & 4.19 \\
\hline Technological intensity & 2.25 & 0.02 & 2.30 & 4.19 & 2.10 & 1.36 & 2.30 & 4.19 \\
\hline Innovation intensity & 0.19 & 0.09 & 2.30 & 4.19 & 0.10 & 1.34 & 2.30 & 4.19 \\
\hline Competitive intensity & 3.27 & 0.42 & 11.92 & 95.49 & 3.40 & 1.16 & 11.92 & 95.49 \\
\hline Role1_idea development & 0.11 & 0.00 & 0.00 & 1.00 & 0.10 & 0.30 & 0.00 & 1.00 \\
\hline Role2_idea implementation & 0.07 & 0.01 & 0.00 & 1.00 & 0.06 & 0.23 & 0.00 & 1.00 \\
\hline Age & 39.00 & 7.07 & 18.00 & 86.00 & 26.10 & 3.88 & 18.00 & 32.00 \\
\hline $\mathrm{Age}^{2}$ & 1521.00 & 49.98 & 324.00 & 7396.00 & 681.21 & 15.05 & 324.00 & 7396.00 \\
\hline Income_higher & 0.42 & 0.01 & 0.00 & 1.00 & 0.40 & 0.49 & 0.00 & 1.00 \\
\hline Gender_male & 0.55 & 0.01 & 0.00 & 1.00 & 0.58 & 0.49 & 0.00 & 1.00 \\
\hline Orgatype_private & 0.65 & 0.05 & 0.00 & 1.00 & 0.73 & 0.44 & 0.00 & 1.00 \\
\hline lnSize & 4.11 & 2.11 & 1.60 & 6.90 & 3.91 & 2.08 & 1.60 & 6.90 \\
\hline
\end{tabular}

Variable

Gen Xers

[8547 employees]

\begin{tabular}{lllll}
\hline & Mean & Std. Dev. & Min & Max \\
Corporate venturing & 0.09 & 0.29 & 0.00 & 1.00 \\
Higher education & 0.32 & 0.47 & 0.00 & 1.00 \\
Managerial experience & 0.11 & 0.31 & 0.00 & 1.00 \\
Entrepreneurial experience & 0.03 & 0.17 & 0.00 & 1.00 \\
Investor experience & 0.06 & 0.24 & 0.00 & 1.00 \\
Entrepreneurial intentions & 0.23 & 0.42 & 0.00 & 1.00 \\
Role models & 0.40 & 0.49 & 0.00 & 1.00 \\
Opportunity perceptions & 0.37 & 0.48 & 0.00 & 1.00 \\
Entrepreneurial skills & 0.50 & 0.50 & 0.00 & 1.00 \\
Fear of failure & 0.44 & 0.50 & 0.00 & 1.00 \\
Autonomy & 3.23 & 1.41 & 1.00 & 5.00 \\
Meaningful job & 3.26 & 1.56 & 1.00 & 5.00 \\
Rewards & 3.19 & 1.34 & 1.00 & 5.00 \\
Labor market conditions & 2.25 & 0.71 & 1.13 & 4.19 \\
Technological intensity & 2.16 & 1.36 & 2.30 & 4.19
\end{tabular}

Baby Boomers

[4888 employees]

\begin{tabular}{llll}
\hline Mean & Std. Dev. & Min & Max \\
0.06 & 0.24 & 0.00 & 1.00 \\
0.28 & 0.45 & 0.00 & 1.00 \\
0.12 & 0.33 & 0.00 & 1.00 \\
0.02 & 0.14 & 0.00 & 1.00 \\
0.06 & 0.23 & 0.00 & 1.00 \\
0.15 & 0.36 & 0.00 & 1.00 \\
0.31 & 0.46 & 0.00 & 1.00 \\
0.32 & 0.47 & 0.00 & 1.00 \\
0.45 & 0.50 & 0.00 & 1.00 \\
0.43 & 0.49 & 0.00 & 1.00 \\
3.20 & 1.46 & 1.00 & 5.00 \\
3.23 & 1.62 & 1.00 & 5.00 \\
3.24 & 1.39 & 1.00 & 5.00 \\
2.25 & 0.62 & 1.13 & 4.19 \\
2.26 & 1.19 & 2.30 & 4.19
\end{tabular}


Table 3 (continued)

\begin{tabular}{|c|c|c|c|c|c|c|c|c|}
\hline \multirow[t]{2}{*}{ Variable } & \multicolumn{4}{|c|}{$\begin{array}{l}\text { Gen Xers } \\
\text { [8547 employees] }\end{array}$} & \multicolumn{4}{|c|}{$\begin{array}{l}\text { Baby Boomers } \\
\text { [4888 employees] }\end{array}$} \\
\hline & Mean & Std. Dev. & Min & Max & Mean & Std. Dev. & Min & Max \\
\hline Innovation intensity & 0.10 & 1.35 & 2.30 & 4.19 & 0.19 & 1.19 & 2.30 & 4.19 \\
\hline Competitive intensity & 3.42 & 1.21 & 11.92 & 95.49 & 3.19 & 1.18 & 11.92 & 95.49 \\
\hline Role1_idea development & 0.11 & 0.32 & 0.00 & 1.00 & 0.11 & 0.31 & 0.00 & 1.00 \\
\hline Role2_idea implementation & 0.08 & 0.26 & 0.00 & 1.00 & 0.08 & 0.27 & 0.00 & 1.00 \\
\hline Age & 40.08 & 4.52 & 33.00 & 48.00 & 55.03 & 4.82 & 49.00 & 86.00 \\
\hline $\mathrm{Age}^{2}$ & 1606.40 & 20.43 & 324.00 & 7396.00 & 3028.30 & 23.23 & 324.00 & 7396.00 \\
\hline Income_higher & 0.42 & 0.49 & 0.00 & 1.00 & 0.39 & 0.49 & 0.00 & 1.00 \\
\hline Gender_male & 0.56 & 0.50 & 0.00 & 1.00 & 0.54 & 0.50 & 0.00 & 1.00 \\
\hline Orgatype_private & 0.62 & 0.49 & 0.00 & 1.00 & 0.53 & 0.50 & 0.00 & 1.00 \\
\hline $\operatorname{lnSize}$ & 4.20 & 2.11 & 1.60 & 6.90 & 4.28 & 2.14 & 1.60 & 6.90 \\
\hline
\end{tabular}

Rodriguez et al. 2003; Yu and Miller 2005) and Gen Xers' technical competence, experience (Cennamo and Gardner 2008; Smola and Sutton 2002), and diversified human capital (Gibson et al. 2009; Smola and Sutton 2002; Wong et al. 2008). Our insights are also aligned with the substantive body of research, which has consistently demonstrated over time that organizational hierarchy has effects on the interest and ability to engage in corporate entrepreneurship (Floyd and Lane 2000; Hornsby et al. 2009; Ren and Guo 2011). Although organizational hierarchy is not measured in this study, the managerial and leading effects observed in Baby Boomers provide some highlights about the relevance of hierarchy in the development of corporate venturing initiatives. Thus, these results support H1a.

Exploring employees' attitudes toward entrepreneurship, we found that fear of failure decreases corporate venturing activities by $24 \%(0.809 ; p<0.010)$. Employees with favorable attitudes toward entrepreneurship, such as intentions to create a business $(2.813 ; p<0.010)$, perceptions of having entrepreneurial skills $(2.160 ; p<0.010)$, knowing entrepreneurs $(1.625 ; p<0.010)$, and perceptions of business opportunities $(1.540 ; p<0.010)$, are more likely to engage in corporate venturing activities than employees who do not have favorable attitudes toward entrepreneurship (supporting H2). These results suggest the relevance of employees' attitudes for corporate venturing activities (Ireland et al. 2009). In fact, reinforcing employees' self-efficacy is one strategy implemented by organizations with an entrepreneurial orientation (Guerrero and Peña-Legazkue 2014, 2019; Khedhaouria et al. 2015; Simon et al. 2000; Van Auken et al. 2006). The analysis for each generation highlights interesting patterns (see Model 1a, 1b, and 1c). First, the positive effect of entrepreneurial intentions on corporate venturing is 0.81 times higher for Baby Boomers $(4.062 ; p<0.010)$ than for Gen Xers (3.249; $p<0.010)$ and 1.82 times higher for Baby Boomers than for Gen Yers $(2.241 ; p<0.010)$. Second, the effect of entrepreneurial skills on corporate venturing is slightly higher in Gen Yers $(2.437 ; p<0.010)$ compared with Gen Xers $(1.841 ; p<0.010)$ and compared with Baby Boomers $(2.368 ; p<0.010)$. Third, the positive effect of entrepreneurial role models and perceptions of opportunities on corporate venturing is similar for all generational cohorts (see Table 4). Our findings are similar to prior studies that have shown the main characteristics per generation in terms of entrepreneurial attitudes, such as Baby Boomers' risk-taking and competitiveness; Gen Xers' efforts to obtain an attractive career; Gen Yers' entrepreneurial spirit, answer-seeking behavior, personal responsibility, need for faster feedback, and focus on outcomes (Eisner 2005; Gibson et al. 2009; Müller and Neck 2010; Smola and Sutton 2002). Thus, our findings support H2a.

Concerning organizational determinants, our findings show some patterns. First, the results lend support to the positive effect of a meaningful job $(1.034 ; p<0.050)$ and rewards $(1.009 ; p<0.100)$ on corporate venturing initiatives. However, we did not find evidence that autonomy affects corporate venturing (Model 1). These results suggest that the employees' engagement in corporate venturing is aligned with their work values and personal aspirations (McMullen and Shepherd 2006), thus supporting H3. One explanation for this finding could be that creating a new venture as part of one's job is an excellent opportunity 


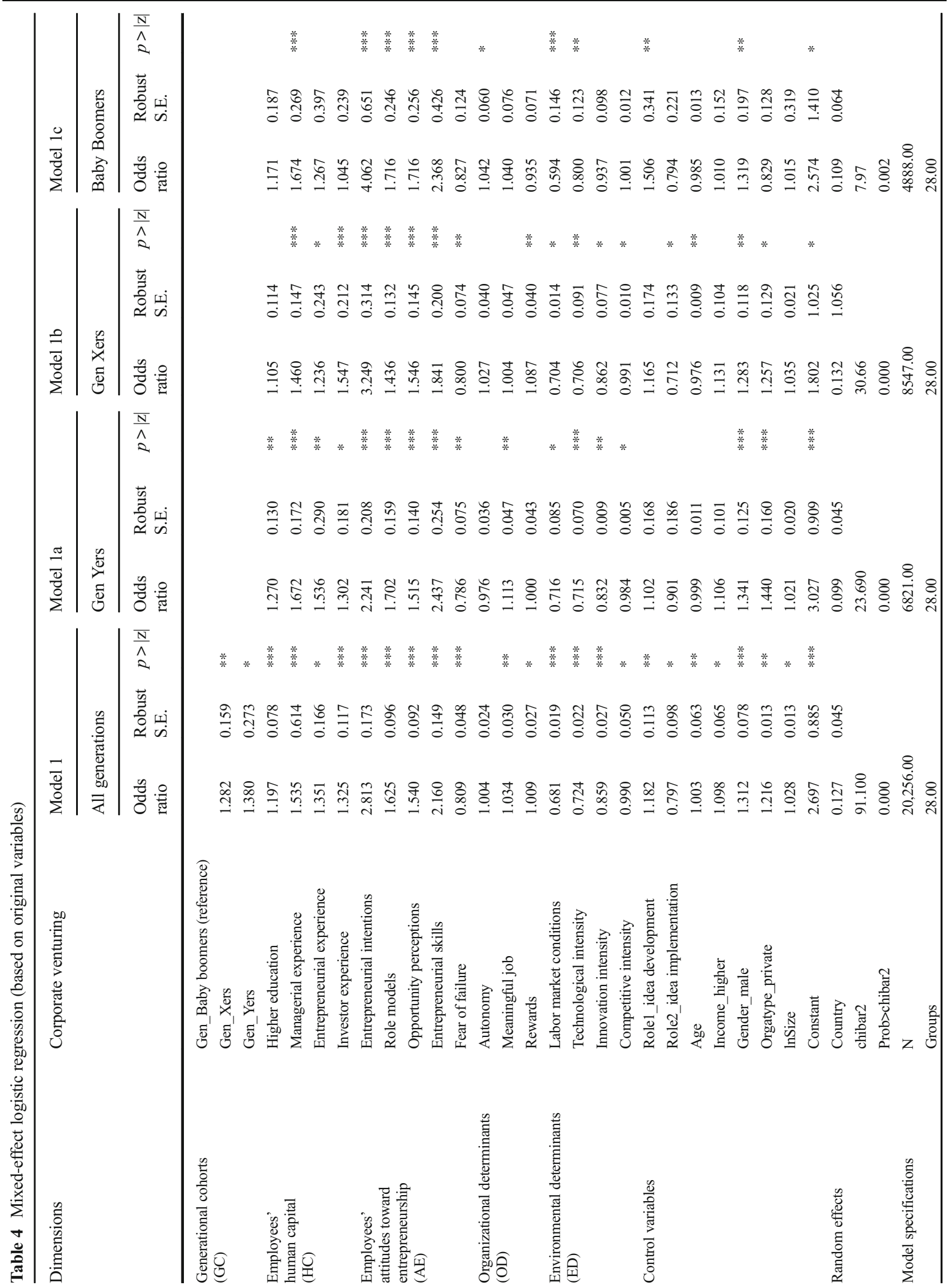




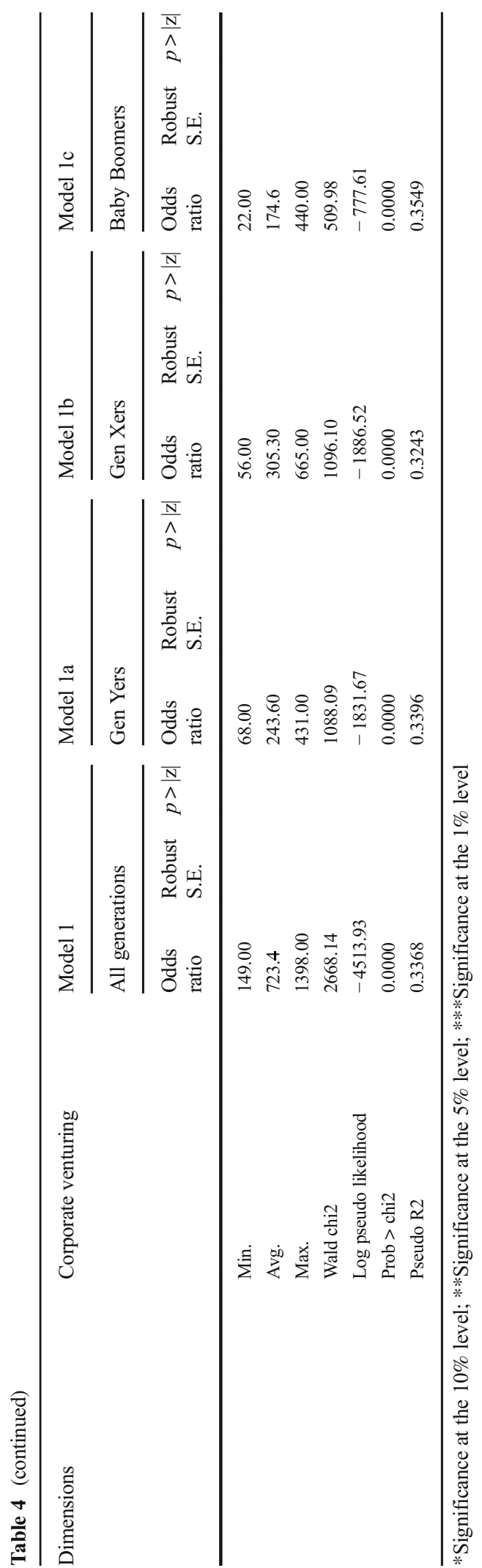

to achieve dreams/goals/values using employer resources and sharing risks (Fairlie 2011; Liden et al. 2000). However, reward involves utility maximization, several tradeoffs, and opportunity costs (Monsen et al. 2010). Therefore, it is not surprising that employees who are more satisfied with their income look for new entrepreneurial opportunities as an alternative to maximizing their utility. Our analysis for each generation provides additional insights. Model 1a shows that the positive effect of meaningful job on corporate venturing is only significant for Gen Yers $(1.113 ; p<0.050)$. Model $1 \mathrm{~b}$ shows that the positive effect of rewards on corporate venturing is only significant for Gen Xers $(1.087 ; p<0.050)$. Model 1c shows that the positive effect of autonomy on corporate venturing is only significant for Baby Boomers (1.042; $p<0.100)$. The influence of generational cohort is evident for this dimension, thus supporting H3a. According to Gibson et al. (2009), Baby Boomers look for autonomy, Gen Xers seek options to improve their salary/benefits, and Gen Yers want to work in a socially active environment. Thus, our results are in line with these prior findings.

With regard to the environmental dimensions (Model 1), unfavorable labor market conditions decrease employees' engagement in corporate venturing by approximately $46 \%(0.681 ; p<0.010)$. Similarly, unfavorable conditions associated with technology intensity decreases employees' engagement in corporate venturing by approximately $38 \%(0.724 ; p<0.010)$. Likewise, unfavorable conditions associated with innovation intensity $(0.859$; $p<0.010$ ) decreases employees' involvement in corporate venturing activities by approximately $16 \%$. A plausible explanation for these results is that approximately $69.16 \%$ of the employees interviewed for the APS during these waves were living in emerging economies ${ }^{8}$, which tend to have nascent entrepreneurial innovation ecosystems (Guerrero and Urbano 2017a, 2017b; Roundy 2017). As a consequence, the absence of favorable environmental conditions does not reinforce employees' involvement in corporate venturing, thus supporting $\mathrm{H} 4$. However, from an organizational perspective, unfavorable environmental conditions could create opportunities to exploit dynamic capabilities and achieve competitive advantages (Ireland et al. 2009; Kuratko et al. 2015). For the different generations, our findings also show the negative influence of environmental conditions. First, the uncertainty in labor market conditions $(0.594 ; p<0.050)$ decreases the Baby

\footnotetext{
$\overline{{ }^{8} \text { See Appendix } 1}$ for further details about the employees' distribution per country.
} 
Boomers' likelihood of engaging in corporate venturing by approximately $67 \%$ (Model 1a). This generation has been profoundly affected by several social, economic, and political events (Gibson et al. 2009; Wong et al. 2008). Therefore, under unfavorable conditions, this generation looks for job security (Yu and Miller 2005). Second, uncertainty in the labor market $(0.704 ; p<0.100)$ and in technology intensity $(0.706 ; p<0.050)$ decrease the probability that Gen Xers are involved in corporate venturing by $42 \%$, respectively (Model 1b). This generation grew up with financial, family, and societal insecurities (Cennamo and Gardner 2008; Smola and Sutton); therefore, this generation prefers avoiding risk in uncertain conditions. Third, the uncertainty in innovation intensity $(0.832$; $p<0.010$ ) decreases the Gen Yers' participation in corporate venturing by approximately $20 \%$ (Model 1c). Interestingly, the negative effect of environmental conditions on corporate venturing is lowest for Gen Yers. This generation grew up under economic uncertainty and insecurities (Gibson et al. 2009) and thus tried to balance organizational purpose and societal objectives (Kowske et al. 2010).

\subsection{Moderation effect of a generational cohort}

Our results suggest that employees' engagement in corporate venture decreases with age. With regard to the moderation effect of having multiple generations in the workplace, Table 5 shows the results for each generation (Model 2) and the generational interactions (Models 2a, $2 \mathrm{~b}$, and $2 \mathrm{c}$ ). Appendix 2 shows graphics that visualize the effects of corporate venturing determinants per generational cohorts 9 .

\footnotetext{
$\overline{{ }^{9} \text { Our interactions }}$ include the dependent variable (corporate venturing), the explanatory variable (theoretical multilevel: individual, organizational and country), and the three-set of generational cohorts (Gen Yers, Gen Xers, and Baby Boomers). Therefore, the use of traditional plots to illustrate interactions represented a complex challenge. Inspired by published studies with complex models in fields such as medicine (Elgendy et al. 2019), sociology (Mize 2019) and business (Hammer et al. 2018), we used the Stata spotlight for creating graphs to visualize our interactions and solve our complexity. According to Huber (2017), the Stata spotlight helps to visualize continuous by continuous interactions with margins and two-way contours. In this vein, based on Model 2 of Table 5, the graph visualizes the impact of different generational cohorts (vertices " $x$ ") and the explanatory variable (vertices " $y$ ") on the probability of employees to be engagement on corporate venturing activities (vertices " $\mathrm{z}$ "). As a result, each interaction causes a curvature of the contour lines in the graph (without interaction, the contour lines would be straight). In other words, the curves in the graph reveal how each generational cohort is associated with the predicted probability of corporate venturing for various levels of human capital, organizational conditions, and environmental conditions.
}

Taking Baby Boomers as a reference, Model 2 shows that employees' engagement in corporate venturing decreases with age and increases with diversified human capital, favorable entrepreneurial attitudes, and favorable organizational conditions. If we analyze the employees' human capital dimensions, Model 2a shows the positive moderation effect for each generational cohort $(1.40 ; p<0.100$ and $1.34 ; p<0.010$ for Gen $\mathrm{X}$ and Gen $\mathrm{Y}$, respectively). Model $2 \mathrm{a}$ also reveals how this interaction reinforces the positive effect of human capital on corporate venturing by 2.1 times $(3.52 ; p<0.050)$ contrasted to Model $2(2.25 ; p<0.050)$. By calculating the predicted probability of corporate venturing per generational cohort (ranging from 18 to 80 years old) and diversified human capital (ranging from 0 to 1), Graph A in Appendix 2 exhibits that a Gen Yer employee (18-34 years old) who has diversified human capital (e.g., simultaneous managerial, entrepreneurial, and investor experiences) has a $40 \%$ chance of developing in corporate venturing activities. Then, a Baby Boomer employee or a Gen Xer employee who has diversified human capital (values close 1) has a 20-30\% chance of engaging corporate venturing activities. Therefore, Gen Yers employees with more diversified human capital have the highest probability of being engaged in corporate venturing initiatives incubated by their employers, while Baby Boomers employees have the lowest likelihood of being involved in corporate venturing.

If we analyze the employees' entrepreneurial attitudes, Model $2 \mathrm{~b}$ shows how the moderation effect for generational cohort $(1.16 ; p<0.100$ and $1.03 ; p<0.100$ for Gen X and Gen Y, respectively) helps to reinforce the positive effect of attitudes toward entrepreneurship on corporate venturing $(2.50 ; p<0.010)$. By calculating the predicted probability of corporate venturing per generational cohort (ranging from 18 to 80 years old) and entrepreneurial attitudes (ranging from 0 to 1), Graph B in Appendix 2 shows that a Gen Yer employee (18-34 years old) who has favorable attitudes toward entrepreneurship (e.g., simultaneous recognizes intentions, role models, skills, opportunities, and failure-aversion) has a $30-40 \%$ chance of developing in corporate venturing activities. A Gen Xer employee who has favorable attitudes toward entrepreneurship has a 20 $30 \%$ chance of engaging corporate venturing activities, while a Baby Boomer employee has a $10 \%$. In this vein, Gen Yers and Gen Xers with favorable attitudes toward entrepreneurship have the highest likelihood of being enrolled in corporate venturing initiatives incubated by 


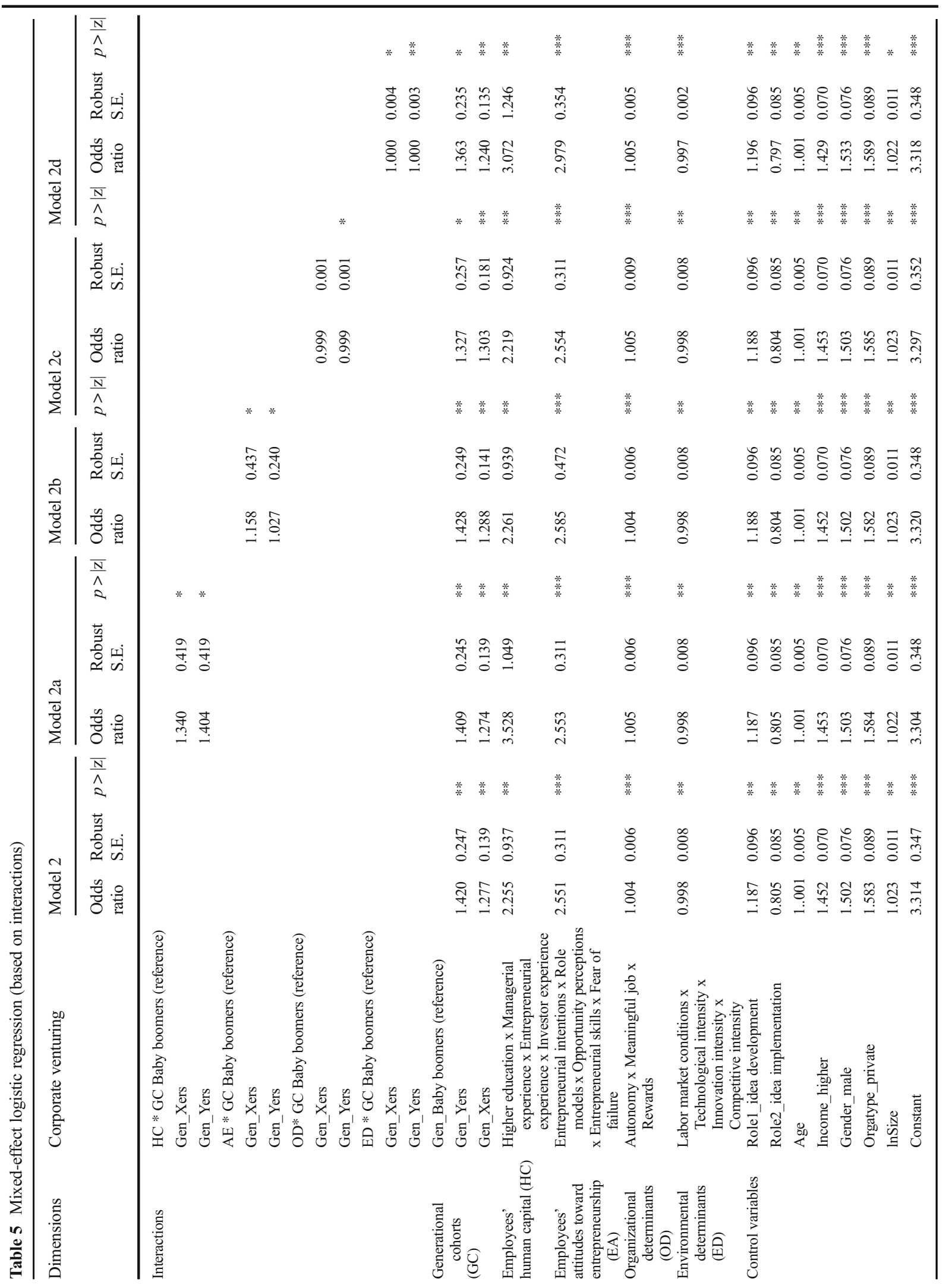




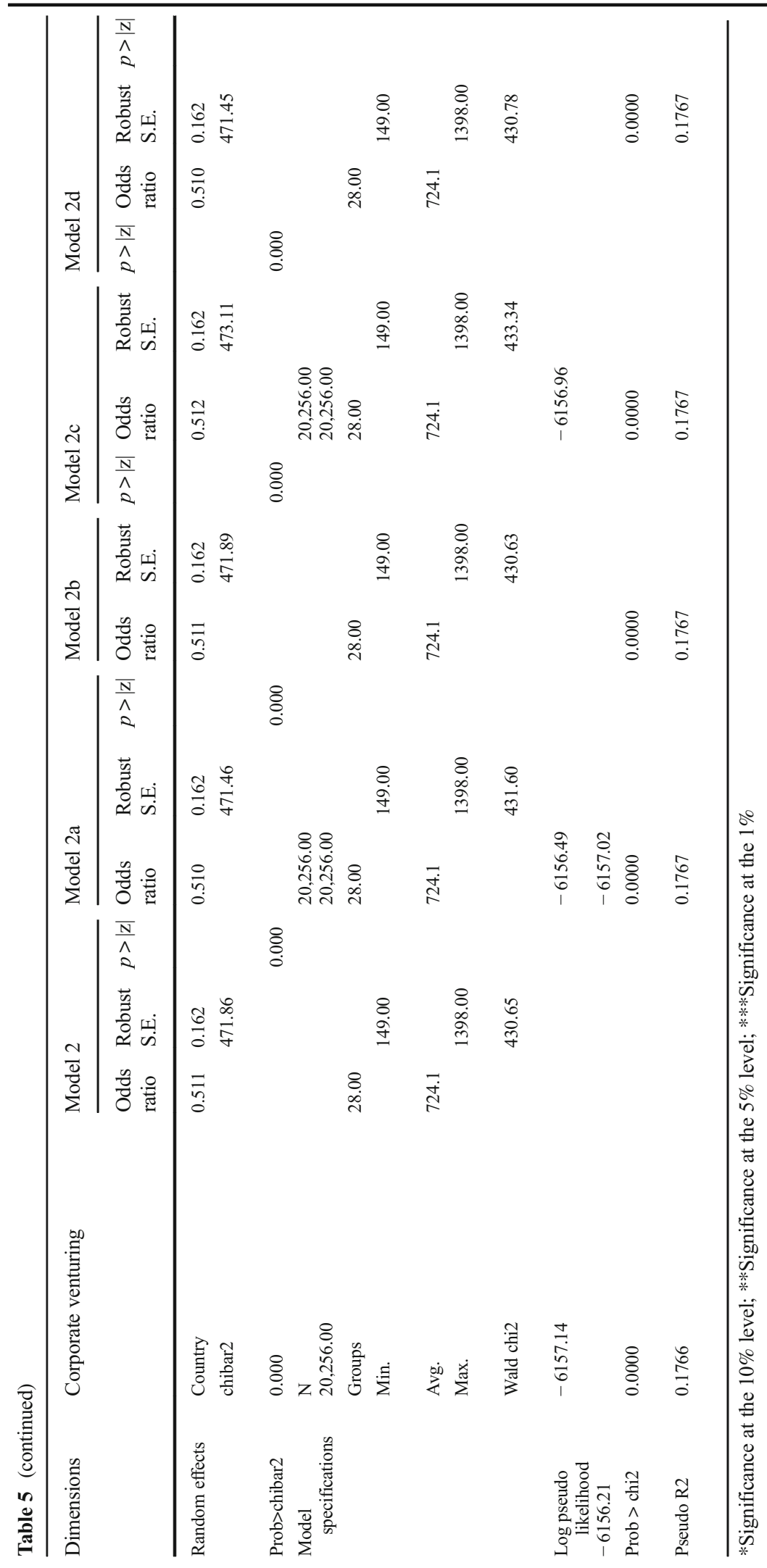


their employers, while Baby Boomers show the lowest probability toward corporate venturing based on their attitudes toward entrepreneurship.

If we analyze the organizational determinants, the generational moderation effect also reinforced the positive influence of organizational determinants on corporate venturing $(1.00 ; p<0.100$ for Gen Yers). By calculating the predicted probability of corporate venturing per generational cohort (ranging from 18 to 80 years old) and favorable organizational conditions (ranging from 1 to 150), Graph $C$ in Appendix 2 shows that a Gen Yer employee (18-34 years old) who has favorable perception of organizational conditions (e.g., autonomy, meaningful job, and rewards) has a 30-50\% chance of developing in corporate venturing activities. A Gen Xer employee who has favorable attitudes toward entrepreneurship has a 10-20\% chance of engaging corporate venturing activities, while a Baby Boomers employee has a $10 \%$. The Gen Yers with favorable perceptions of the organizational climate are more prone to participate in corporate venturing, while the Gen Xers and Baby Boomers with favorable perceptions of organizational climate are lower participative on corporate venturing.

If we analyze the environmental determinants, the moderation effect of generations on the negative influence of environmental determinants on corporate venturing $(0.99 ; p<0.100$ for both Gen Xers and Gen Yers) indicate odds ratio close to 1 ; therefore, the interpretation could be positive or negative (Model 2c and Model $2 \mathrm{~d})$. By calculating the predicted probability of corporate venturing per generational cohort (ranging from 18 to 80 years old) and environmental determinants (ranging from 1 to 150), Graph D in Appendix 2 shows that a Gen Yer employee (18-34 years old) who has favorable perception of environmental conditions (e.g., labor market conditions, technological intensity, innovation intensity, and competitive intensity) has a $20 \%$ chance of developing in corporate venturing activities. A Gen Xer employee or Baby Boomer employee or who has favorable perceptions of environmental conditions has a $10 \%$ chance of engaging corporate venturing activities. Therefore, the lowest negative effect of environmental conditions on corporate venturing is observed in the Gen Yers.

Related control variables employees' age is significant in all interactions models, corroborating that "older" employees in each generational cohort have more propensity to be corporate entrepreneurs. Related to employees' gender male also positive and significant.
The higher employees' income also increases the probability to be corporate entrepreneurs. At the organizational level, be involved in the leading role in the development (role 1_development) and/or leading role in the implementation (role 2 implementation) is positive and significant. Similarly, the organization size (InSize) and work in private organizations (Orgatype Private) are positive and significant for corporate venturing.

In sum, the moderation models reveal how generational cohort positively reinforces the effect of each determinant on corporate venturing. Appendix 2 visually reveals how the interaction term causes the curvatures of the contour lines. These curvatures show how the positive effect of generational cohorts on the predicted probability of corporate venturing differs across levels of corporate venturing determinants (human capital, attitudes, organizational conditions, and environmental conditions) and vice versa (supporting H1a, H2a, H3b, and H4b). According to Deloitte (2017), current organizations need a guide for attracting, developing, and retaining millennial talent based on their concerns and motivations. Based on the answers of 80,000 Gen Yers across 30 countries, the most recent Deloitte Millennial Survey (Deloitte 2017) shows that (1) environmental factors influence Millennials' aspirations (e.g., pessimism is prevalent in developed countries, while optimism reigns in emerging countries) and loyalty to employers; (2) their perceptions of entrepreneurship are positive, but they believe entrepreneurship does not fully realize its potential to alleviate the world's biggest challenges (e.g., they are more likely to feel empowered while reinforcing a balance between business activities and social impact); and (c) their perceptions about work environments are looking for trust, flexible work, loyalty, significant contributions, creative thinking, and opportunities to develop new skills. The Forbes Millennials Survey of 1332 candidates under 30 years old provides similar insights about how Gen Yers are motivated by inspiration, ambitions, and optimism (Forbes 2017).

\section{Conclusions}

The objective of this paper was to provide insights into how employees' human capital/attitudes, organizational determinants, and environmental determinants of corporate venturing are influenced by employees' generational cohort. Conducting an exploratory inductive study (Frederick and Monsen 2011), we developed 
hypotheses about the effects of human capital (H1), attitudes toward entrepreneurship (H2), organizational determinants (H3), and environmental conditions (H4) on corporate venturing activities as well as the moderation effect of having multiple generation in today's workplace (H1a, H2a, H3a, and H4a). In this regard, this paper contributes at least with three contributions to the ongoing academic debate on the influence of employees' age and corporate entrepreneurship.

The first contribution relates to the effects of human capital and attitudes toward entrepreneurship on corporate venturing for different generational cohorts. Our results showed the complexity of exploring the influence of attitudes (Twenge 2010; Costanza et al. 2012), skills, abilities, and experience (Burton et al. 2016b; Lyons and Kuron 2014; Lyons et al. 2012; Engel et al. 2017) across generational cohorts. Although we provided some insights into generational similarities, each generation showed certain particularities in terms of their entrepreneurial skills and attitudes, which, in turn, influences the development of corporate entrepreneurship activities within organizations. In our empirical setting, it was very complicated to separate the unique human capital characteristics of each generational cohort as almost all of these characteristics were observed across cohorts. However, the effect produced is different. Indirectly, our results updated/ mapped the key competences of the workforce in terms of human capital and attitudes toward entrepreneurship. In this regard, Lyons and Kuron (2014) highlighted that the labor force is becoming more independent and self-focused. Younger generations (i.e., Gen Yers) are generally less committed to their organizations, making them more "itinerant" in their careers, and they are pursuing personal fulfillment in their work. Thus, employers and other leaders could develop corporate venturing initiatives to satisfy these "individualistic growth needs." Having corporate venturing programs could also be a way to generate a competitive advantage in attracting and retaining talent (Lyons and Kuron 2014). Work teams that include individuals from multiple generations will also likely lead to workplaces characterized by creativity, flexibility, and a combination of short- and long-term achievements (Kuratko et al. 2015). Moreover, the analysis of human capital and attitudes per generational cohorts also demand new conceptual approaches and empirical evidence about the career choices' generational determinants of collectives like employees, intrapreneurs, and entrepreneurs and if this characteristics could be "transmitted" by different generations (Hout and Rosen, 2000; Zellweger et al. 2011;
Raffiee and Feng 2014; Roach and Sauermann 2015a, 2015b; Sieger and Monsen 2015; Zhang and Acs 2018).

Our second contribution relates to the organizational determinants of corporate venturing. Our insights highlighted the influence of work design and climate (autonomy, a meaningful job, and rewards) on corporate venturing (James et al. 2011; Rigtering and Weitzel 2013; King and Bryant 2017). Our analysis revealed unique patterns related to organizational determinants for each generation. Namely, certain particularities were more intense for the different generations based on their values/expectations. For example, Gen Yers are looking for more meaningful workplaces and are more motivated by rewards, and Gen Xers are more interested in autonomy. Therefore, these insights are very useful for strategic managers and human resource teams interested in creating innovative entrepreneurial teams. For human resource managers, these insights could guide the (re) design of current tasks/jobs according to organizations' goals and the current/future workforce's human capital. For example, unlike for the youngest generation, digitalization in the workplace is producing intense challenges for organizations' oldest employees, who generally have strong experience but also strong aversion to change. This issue implies the need to reconfigure jobs within entrepreneurial organizations to foster the development of corporate venturing activities (Gibson et al. 2009; Colombo et al. 2016a, 2016b) as well as the incentives for employees' engagement (Bloom and Van Reenen 2010; Deloitte 2017; Forbes 2017).

Finally, our third contribution relates to the influence of environmental determinants on corporate venturing. It is generally accepted that environmental conditions are key determinants of corporate venturing strategies (Wright and Hitt 2017). However, our results provide insights into how employees from different generations may perceive environmental conditions similarly/ differently (Twenge et al. 2010; Colombo et al. 2016a). For policymakers, our results provide some insights into the effect of external conditions on corporate venturing. In this regard, governmental programs also need to be configured to support organizations with entrepreneurial orientation and should directly or indirectly reinforce entrepreneurial ecosystems (Autio et al. 2014; Ayyagari et al. 2014) with particular emphasis on emerging economies (Roundy 2017).

In addition to these contributions, we acknowledge that this study has several limitations. First, the GEM survey provided a set of general measures/items and 
only included a few questions concerning special topics. For this reason, our proxies for the organizational determinants were based on subjective measures, such as employees' perceptions. To overcome this limitation, future work could apply constructs used in previous studies as well as combine objective measures. Second, given the nature of our dataset, we do not have extended information about the employees' life trajectories in a panel approach (Dunn and Holtz-Eakin 2000). Therefore, we defined the multigenerational cohorts only by age category without controlling or contrasting other elements associated with defining generational cohorts. Future work should use robust variables and datasets to understand generational cohorts. In addition, the results illustrate a U-shaped relationship between corporate entrepreneurship and generational cohorts (Bönte et al. 2009). By multicollinearity problems with the main explanatory variables (Allen 1997), the analysis did not include age square as previous studies (Parker 2011; Ganotakis 2012; Ouimet and Zarutskie 2014). However, contrarily to other previous studies (Bönte et al. 2009; Zhang and Acs 2018), we provided some insights about how the probability of being involved in corporate venturing decreases with the age or generational cohorts. However, it implies an in-depth analysis of the generational cohorts of employees and their involvement in corporate venturing activities in different environments. Third, our measures for the external context should also be improved for different types of economies. By multicollinearity problems with the main explanatory variables (Allen 1997), the analysis did not include other environmental conditions like the GDP per capita (Frederick and Monsen 2011) or the total entrepreneurial activity per country (Monsen et al. 2012). This limitation opens up opportunities to analyze the influence of other environmental conditions on corporate venturing using novel instrumental variables. Published GEM studies have shown that the entrepreneurial activity of employees is highest observed in countries with lower levels of TEA (Bosma 2013). In this respect, it could be interesting to explore the reverse relationship between corporate entrepreneurship and GDP per capita (Edward et al. 2004; Dell et al. 2012), to theorize about the relationship between the influence of individual entrepreneurship (entrepreneurial density) on corporate entrepreneurship per country (Bosma et al. 2010, 2013), or to understand the role of gender/labor equalities on corporate entrepreneurship per country (Ruiz et al. 2019).
Fourth, research on generational cohorts demands more theory development using multiple approaches. In this study, our conceptual framework was supported by previous studies from the strategic management and entrepreneurship pieces of literature and adopting theories like human capital, organizational behavior, and institutional theory. In this vein, future work should reinforce our proposed model from mixed theoretical approaches: sociological and psychological approaches at the individual level (Zhang and Acs 2018); dynamic capabilities and organizational behaviors perspective at the organizational level (Lui et al., 2019); and institutional economics and entrepreneurial identities at the country level (Yusoff et al. 2019). Fifth, based on the nature of the dataset, we used mixed-effect logistic regressions to test our hypotheses as well as interactions for exploring the moderation role of generational cohorts on the determinants of corporate venturing. Therefore, more qualitative and quantitative longitudinal analyses in future research will help develop a better understanding of the complexity of this phenomenon. The implementation of novel statistic techniques (e.g., structural equation models, multi-groups, multilevel, and experiments) is also needed to understand the complexity behind the role of generational cohorts on corporate venturing activities. Sixth, considering the substantial body of literature that has related corporate venturing and organizational hierarchy (Floyd and Lane 2000; Hornsby et al. 2009; Ren and Guo 2011) and the lack of information about the employees' hierarchy limited the analysis of this variable per generational cohort, a natural extension of this study is exploring in-depth the employees' trajectory and current position within the parent venture (Parker 2011). This analysis will highlight the relevance of hierarchy for promoting, developing and leading entrepreneurial initiatives across diverse generations of employees, intrapreneurs, and entrepreneurs (e.g., the transition from the employee toward entrepreneurial employee or self-employment).

Acknowledgments The authors would like to thank the anonymous reviewers for their insightful comments that contributed substantially to the development of our manuscripts.

Finding information David Urbano acknowledges the financial support from the Spanish Ministry of Economy \& Competitiveness [project ECO2017-87885-P], the Economy \& Knowledge Department-Catalan Government [project 2017-SGR-1056] and ICREA under the ICREA Academia Programme. 


\section{Appendix 1}

Table 6 Employees' distribution per generation and country

\begin{tabular}{|c|c|c|c|c|}
\hline \multirow[t]{2}{*}{ Country } & \multicolumn{4}{|c|}{ Employees' distribution } \\
\hline & Baby Boomers & Gen Xers & Gen Yers & Total \\
\hline Belgium & $2 \%$ & $2 \%$ & $4 \%$ & $2 \%$ \\
\hline Bosnia and Herzegovina & $3 \%$ & $3 \%$ & $4 \%$ & $3 \%$ \\
\hline Chile & $5 \%$ & $5 \%$ & $6 \%$ & $5 \%$ \\
\hline China & $1 \%$ & $7 \%$ & $5 \%$ & $7 \%$ \\
\hline Croatia & $2 \%$ & $3 \%$ & $3 \%$ & $2 \%$ \\
\hline Denmark & $3 \%$ & $3 \%$ & $4 \%$ & $3 \%$ \\
\hline Ecuador & $3 \%$ & $2 \%$ & $2 \%$ & $2 \%$ \\
\hline Estonia & $2 \%$ & $2 \%$ & $5 \%$ & $3 \%$ \\
\hline Finland & $3 \%$ & $2 \%$ & $5 \%$ & $3 \%$ \\
\hline Greece & $1 \%$ & $1 \%$ & $1 \%$ & $1 \%$ \\
\hline Hungary & $4 \%$ & $5 \%$ & $6 \%$ & $5 \%$ \\
\hline Iran & $6 \%$ & $4 \%$ & $2 \%$ & $4 \%$ \\
\hline India & $2 \%$ & $2 \%$ & $1 \%$ & $2 \%$ \\
\hline Lithuanian & $5 \%$ & $5 \%$ & $7 \%$ & $5 \%$ \\
\hline Malaysia & $5 \%$ & $5 \%$ & $3 \%$ & $4 \%$ \\
\hline Nambia & $6 \%$ & $2 \%$ & $1 \%$ & $3 \%$ \\
\hline Nigeria & $2 \%$ & $1 \%$ & $1 \%$ & $1 \%$ \\
\hline Peru & $4 \%$ & $2 \%$ & $2 \%$ & $3 \%$ \\
\hline Philippines & $1 \%$ & $1 \%$ & $1 \%$ & $1 \%$ \\
\hline Poland & $2 \%$ & $2 \%$ & $3 \%$ & $2 \%$ \\
\hline Puerto Rico & $1 \%$ & $1 \%$ & $1 \%$ & $1 \%$ \\
\hline Romania & $4 \%$ & $4 \%$ & $4 \%$ & $4 \%$ \\
\hline Slovakia & $4 \%$ & $5 \%$ & $7 \%$ & $5 \%$ \\
\hline Slovenia & $3 \%$ & $5 \%$ & $7 \%$ & $0 \%$ \\
\hline South Korea & $3 \%$ & $4 \%$ & $4 \%$ & $4 \%$ \\
\hline United Kingdom & $15 \%$ & $14 \%$ & $3 \%$ & $17 \%$ \\
\hline Uruguay & $4 \%$ & $3 \%$ & $4 \%$ & $4 \%$ \\
\hline Vietnam & $4 \%$ & $3 \%$ & $2 \%$ & $3 \%$ \\
\hline Total & $100 \%$ & $100 \%$ & $100 \%$ & $100 \%$ \\
\hline
\end{tabular}

Source: Authors 


\section{Appendix 2}

Graph A.

Employees' human capital, generational cohorts, and corporate venturing probability

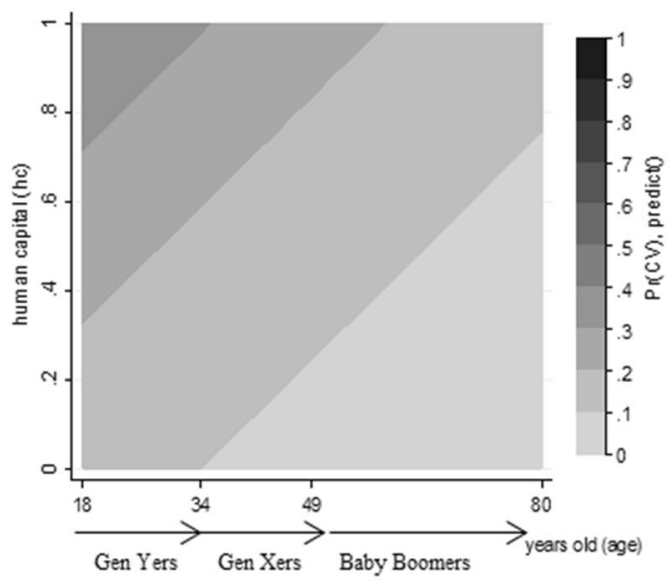

Graph C.

Organizational determinants, generational cohorts, and corporate venturing probability

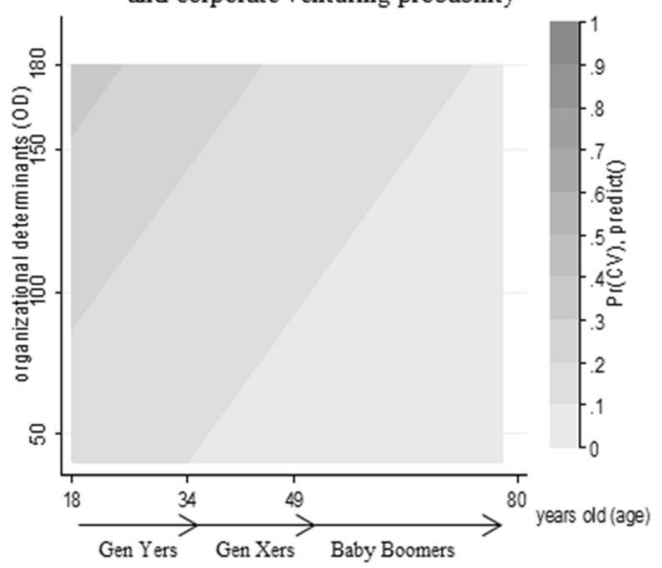

Fig. 2 Marginal effects* between corporate venturing and determinants per generation. *Methodological note: These graphs were created using Stata spotlight that helps to visualize continuous by continuous interactions with margins and two-way contours. For further details about how to compute and interpret the Stata spotlight, please

\section{Graph B.}

Employees' entrepreneurial attitudes, generational cohorts, and corporate venturing probability

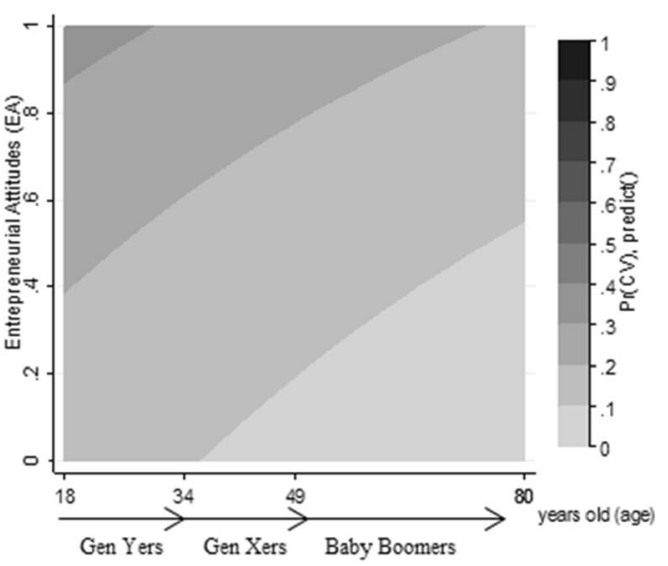

Graph D.

Environment determinants, generational cohorts, and corporate venturing probability

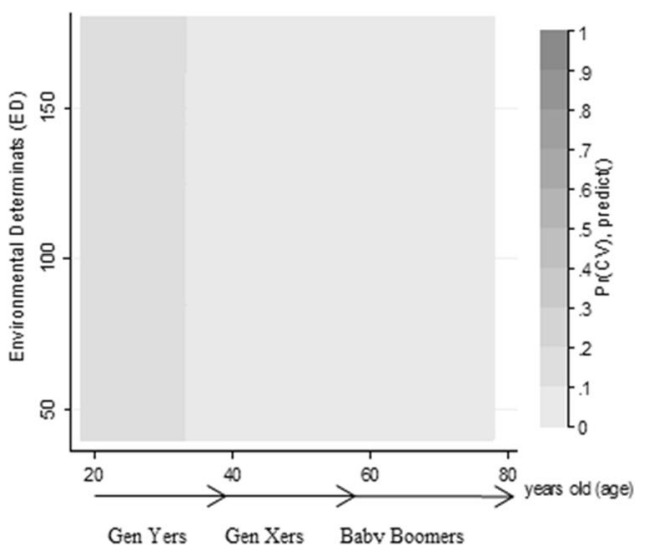

review the Stata commands developed by Huber (2017), as well as published studies from multiple fields that have used the Stata spotlight for explaining models with complex interactions (see Hammer et al. 2018; Elgendy et al. 2019; Mize 2019) 
Open Access This article is licensed under a Creative Commons Attribution 4.0 International License, which permits use, sharing, adaptation, distribution and reproduction in any medium or format, as long as you give appropriate credit to the original author(s) and the source, provide a link to the Creative Commons licence, and indicate if changes were made. The images or other third party material in this article are included in the article's Creative Commons licence, unless indicated otherwise in a credit line to the material. If material is not included in the article's Creative Commons licence and your intended use is not permitted by statutory regulation or exceeds the permitted use, you will need to obtain permission directly from the copyright holder. To view a copy of this licence, visit http://creativecommons.org/licenses/by/4.0/.

\section{References}

Aiken, L. S., West, S. G., \& Reno, R. R. (1991). Multiple regression: Testing and interpreting interactions. US: Sage.

Allen, M. (1997). The problem of multicollinearity. In: Understanding regression analysis. Springer, Boston, MA.

Alpkan, L., Bulut, C., Gunday, G., Ulusoy, G., \& Kilic, K. (2010). Organizational support for intrapreneurship and its interaction with human capital to enhance innovative performance. Management Decision, 48(5), 732-755.

Alrumaithi, E., Guerrero, M., Peña, I. 2015. The role of employee's human capital and the work environment on the creation of organizational spin-offs: Evidence from Spain. In entrepreneurship, human capital, and regional development. Springer international publishing: UK; 59-74.

Amabile, T., \& Kramer, S. (2011). The progress principle: Using small wins to ignite joy, engagement, and creativity at work. US: Harvard Business Press.

Antoncic, B., \& Hisrich, R. D. (2001). Intrapreneurship: Construct refinement and cross-cultural validation. Journal of Business Venturing, 16(5), 495-527.

Antoncic, J., \& Antoncic, B. (2011). Employee satisfaction, intrapreneurship, and firm growth: A model. Industrial Management \& Data Systems, 111(4), 589-607.

Autio, E., Kenney, M., Mustar, P., Siegel, D., \& Wright, M. (2014). Entrepreneurial innovation: The importance of context. Research Policy, 43(7), 1097-1108.

Awogbenle, A. C., \& Iwuamadi, K. C. (2010). Youth unemployment: Entrepreneurship development programme as an intervention mechanism. African Journal of Business Management, 4(6), 831-835.

Ayyagari, M., Demirguc-Kunt, A., \& Maksimovic, V. (2014). Who creates jobs in developing countries? Small Business Economics, 43(1), 75-99.

Becker, G. S. (1964). Human capital. Chicago: The University of Chicago Press.

Becker, G. S. (2002). The age of human capital. In H. Lauder, P. Brown, J. Dillabough, \& H. Halsey (Eds.), Education, globalization \& social change (pp. 292-295). Oxford, UK: Oxford University Press.

Benson, J., \& Brown, M. (2011). Generations at work: Are there differences and do they matter? The International Journal of Human Resource Management, 22(9), 1843-1865.
Bindl U., Parker S. K. 2010. Proactive work behavior: Forwardthinking and change-oriented action in organizations. American Psychological Association: Washington, DC; 567-598.

Bloom N., Lemos R., Sadun R., Scur D., Van Reenen J. 2014. The new empirical economics of management. NBER Working Papers.

Bloom, N., \& Van Reenen, J. (2010). Why do management practices differ across firms and countries? The Journal of Economic Perspectives, 24(1), 203-224.

Bönte, W., Falck, O., \& Heblich, S. (2009). The impact of regional age structure on entrepreneurship. Economic Geography, $85(3), 269-287$.

Bosma, N. (2013). The global entrepreneurship monitor (GEM) and its impact on entrepreneurship research. Foundations and Trends in Entrepreneurship, 9, 143-248.

Bosma, N. S., Stam, F. C., \& Wennekers, A. R. M. (2010). Intrapreneurship: An international study. Scales: Utrecht University.

Bosma, N., Wennekers, S., Guerrero, M., Amorós, J. E., Martiarena, A., \& Singer, S. (2013). Global entrepreneurship monitor special report on entrepreneurial employee activity. London: Global Entrepreneurship Research Association.

Burton M. D., Dahl M. S., Sorenson O. 2016a. Do startups create good jobs?. Working Paper.

Burton, M. D., Sørensen, J. B., \& Dobrev, S. D. (2016b). A careers perspective on entrepreneurship. Entrepreneurship Theory and Practice, 40(2), 237-247.

Cennamo, L., \& Gardner, D. (2008). Generational differences in work values, outcomes and person-organisation values fit. Journal of Managerial Psychology, 23(8), 891-906.

Chen, P. J., \& Choi, Y. (2008). Generational differences in work values: A study of hospitality management. International Journal of Contemporary Hospitality Management, 20(6), 595-615.

Colombo, M. G., Piva, E., Quas, A., \& Rossi-Lamastra, C. (2016a). How high-tech entrepreneurial ventures cope with the global crisis: Changes in product innovation and internationalization strategies. Industry and Innovation, 23(7), 647-671.

Colombo, M. G., Rossi-Lamastra, C., \& Matassini, B. (2016b). The organizational design of high-tech entrepreneurial ventures. Foundations and Trends ${ }^{\circledR}$ in Entrepreneurship, 11(6), 427-523.

Costanza, D. P., Badger, J. M., Fraser, R. L., Severt, J. B., \& Gade, P. A. (2012). Generational differences in work-related attitudes: A meta-analysis. Journal of Business and Psychology, 27(4), 375-394.

De Meulenaere, K., Boone, C., \& Buyl, T. (2016). Unravelling the impact of workforce age diversity on labor productivity: The moderating role of firm size and job security. Journal of Organizational Behavior, 37(2), 193-212.

Dell, M., Jones, B. F., \& Olken, B. A. (2012). Temperature shocks and economic growth: Evidence from the last half-century. American Economic Journal: Macroeconomics, 4(3), 66-95.

Deloitte. (2017). The 2017 Deloitte millennial survey. UK: Deloitte Touche Tohmatsu Limited https://www2.deloitte. com/content/dam/Deloitte/global/Documents/About-Deloitte/gxdeloitte-millennial-survey-2017-executive-summary.pdf.

Dose, J. (1997). Work values: An integrative framework and illustrative application to organizational socialization. Journal of Occupational and Organizational Psychology, 70, 219-241.

Douglas, E. J., \& Shepherd, D. A. (2002). Self-employment as a career choice: Attitudes, entrepreneurial intentions, and utility maximization. Entrepreneurship Theory and Practice, 26(3), $81-90$. 
Dunn, T., \& Holtz-Eakin, D. (2000). Financial capital, human capital, and the transition to self-employment: Evidence from intergenerational links. Journal of Labor Economics, 18(2), 282-305.

Edward, M., Satyanath, S., \& Sergenti, E. (2004). Economic shocks and civil conflict: An instrumental variables approach. Journal of Political Economy, 112(4), 725-753.

Eisner, S. P. (2005). Managing generation Y. SAM Advanced Management Journal, 70(4), 4-15.

Elam, A. B. (2014). Gender and entrepreneurship. Edward Elgar Publishing.

Elgendy, R., Deschênes, S. S., Burns, R. J., Levy, M., \& Schmitz, N. (2019). Alcohol consumption, depressive symptoms, and the incidence of diabetes-related complications. Journal of Diabetes, 11(1), 14-22.

Engel, Y., van Burg, E., Kleijn, E., \& Khapova, S. N. (2017). Past career in future thinking: How career management practices shape entrepreneurial decision making. Strategic Entrepreneurship Journal, 11, 122-144.

European Commission. 2012. The 2012 aging report: Economic and budgetary projections for the $27 \mathrm{EU}$ member states (2010-2060). http://ec.europa.eu/economy finance/publications/european_economy/2012/2012ageing-report en.htm

Fairlie, P. (2011). Meaningful work, employee engagement, and other key employee outcomes: Implications for human resource development. Advances in Developing Human Resources, 13(4), 508-525.

Fehr, E., \& Schmidt, K. M. (2007). Adding a stick to the carrot? The interaction of bonuses and fines. The American Economic Review, 97(2), 177-181.

Floyd, S. W., \& Lane, P. J. (2000). Strategizing throughout the organization: Managing role conflict in strategic renewal. Academy of Management Review, 25(1), 154-177.

Forbes. (2017). Forbes Millennials. 30 under 30 survey candidate results. Forbes: US http://info.forbes.com/2017-U30-SurveyResults.html.

Frederick, H., \& Monsen, E. (2011). New Zealand's perfect storm of entrepreneurship and economic development. Small Business Economics, 37(2), 187-204.

Fuller, J. B., Marler, L. E., \& Hester, K. (2006). Promoting felt responsibility for constructive change and proactive behavior: Exploring aspects of an elaborated model of work design. Journal of Organizational Behavior, 27(8), 1089-1120.

Ganotakis, P. (2012). Founders' human capital and the performance of UK new technology based firms. Small Business Economics, 39(2), 495-515.

Garrett R. P., Miao C., Qian S., Bae T. J. 2017. Entrepreneurial spawning and knowledge-based perspective: A meta-analysis. Small business economics 1-24.

Gibson, J. W., Greenwood, R. A., \& Murphy Jr., E. F. (2009). Generational differences in the workplace: Personal values, behaviors, and popular beliefs. Journal of Diversity Management, 4(3), 1.

Gnyawali, D. R., \& Fogel, D. S. (1994). Environments for entrepreneurship development: Key dimensions and research implications. Entrepreneurship Theory and Practice, 18, 43-43.

Grégoire, D. A., Barr, P. S., \& Shepherd, D. A. (2010). Cognitive processes of opportunity recognition: The role of structural alignment. Organization Science, 21(2), 413-431.

Guerrero, M., \& Peña-Legazkue, I. (2013). The effect of intrapreneurial experience on corporate venturing: Evidence from developed economies. International Entrepreneurship and Management Journal, 9(3), 397-416.

Guerrero, M., \& Peña-Legazkue, I. (2014). The effect of human capital on firm creation: Evidence from Spain (p. 27). Entrepreneurship, People and Organisations: Frontiers in European Entrepreneurship Research.

Guerrero, M., \& Urbano, D. (2017a). The impact of triple Helix agents on entrepreneurial innovations' performance: An inside look at enterprises located in an emerging economy. Technological Forecasting and Social Change, 119, 294-309.

Guerrero, M., \& Urbano, D. (2017b). Higher education entrepreneurial ecosystems: Exploring the role of business incubators in an emerging economy. IRE, 15(2), 175-202.

Guerrero, M., \& Peña-Legazkue, I. (2019). Renascence after postmortem: The choice of accelerated repeat entrepreneurship. Small Business Economics, 52(1), 47-65.

Guo, G., \& Zhao, H. (2000). Multilevel modelling for binary data. Annual Review of Sociology, 26(1), 441-462.

Guth, W., \& Ginsberg, A. (1990). Guest editors introduction: Corporate entrepreneurship the promise of entrepreneurship as a field of research. Strategic Management Journal, 11(5), 5-11.

Hammer, B., Hinrichs, H., \& Schwetzler, B. (2018). Does culture affect the performance of private equity buyouts? Journal of Business Economics, 88(3-4), 393-469.

Hastie, R. (2001). Problems for judgment and decision making. Annual Review of Psychology, 52, 653-683.

Hayton, J. C. (2005). Competing in the new economy: The effect of intellectual capital on corporate entrepreneurship in hightechnology new ventures. $R \& D$ Management, 35(2), 137-155.

Hornsby, J. S., Kuratko, D. F., \& Zahra, S. A. (2002). Middle managers' perception of the internal environment for corporate entrepreneurship: Assessing a measurement scale. Journal of Business Venturing, 17(3), 253-273.

Hornsby, J., Peña-Legazkue, I., \& Guerrero, M. (2013). Guest editorial: The role of corporate entrepreneurship in the current organizational and economic landscape. International Entrepreneurship and Management Journal, 9(3), 295-305.

Hornsby, J. S., Kuratko, D. F., Shepherd, D. A., \& Bott, J. P. (2009). Managers' corporate entrepreneurial actions: Examining perception and position. Journal of Business Venturing, 24(3), 236-247.

Hout, M., \& Rosen, H. (2000). kSelf \$ Employment. Family Background and Race, Journal of Human Resources, 35(4).

Huber, C. 2017. In the spotlight: Visualizing continuous-bycontinuous interactions with margins and two-way contour. Stata news, 32 (1), retrieved June 15, 2019. Https: //www. stata.com/stata-news/news32-1/spotlight/.

Hung, K. H., Gu, F. F., \& Yim, C. K. B. (2007). A social institutional approach to identifying generation cohorts in China with a comparison with American consumers. Journal of International Business Studies, 38(5), 836-853.

Ireland, R. D., Covin, J. G., \& Kuratko, D. F. (2009). Conceptualizing corporate entrepreneurship strategy. Entrepreneurship Theory and Practice, 33(1), 19-46.

James, J. B., McKechnie, S., \& Swanberg, J. (2011). Predicting employee engagement in an age diverse retail workforce. Journal of Organizational Behavior, 32(2), 173-196.

Khedhaouria, A., Gurău, C., \& Torrès, O. (2015). Creativity, selfefficacy, and small-firm performance: The mediating role of entrepreneurial orientation. Small Business Economics, 44(3), 485-504. 
King, S. P., \& Bryant, F. B. (2017). The workplace intergenerational climate scale (WICS): A self-report instrument measuring ageism in the workplace. Journal of Organizational Behavior, 38(1), 124-151.

Knudsen, E. S., \& Lien, L. B. (2015). Hire, fire, or train: Innovation and human capital responses to recessions. Strategic Entrepreneurship Journal, 9(4), 313-330.

Koellinger, P. D., \& Thurik, A. (2012). Entrepreneurship and the business cycle. Review of Economics and Statistics, 94(4), 1143-1156.

Kooij, D. T., De Lange, A. H., Jansen, P. G., Kanfer, R., \& Dikkers, J. S. (2011). Age and work-related motives: Results of a metaanalysis. Journal of Organizational Behavior, 32(2), 197-225.

Kowske, B. J., Rasch, R., \& Wiley, J. (2010). Millennials'(lack of) attitude problem: An empirical examination of generational effects on work attitudes. Journal of Business and Psychology, 25(2), 265-279.

Kuratko, D. F., Hornsby, J. S., \& Bishop, J. W. (2005a). Managers' corporate entrepreneurial actions and job satisfaction. The International Entrepreneurship and Management Journal, 1(3), 275-291.

Kuratko, D. F., Hornsby, J. S., \& Hayton, J. (2015). Corporate entrepreneurship: The innovative challenge for a new global economic reality. Small Business Economics, 45(2), 245-253.

Kuratko, D. F., Ireland, R. D., Covin, J. G., \& Hornsby, J. S. (2005b). A model of middle-level managers' entrepreneurial behavior. Entrepreneurship Theory and Practice, 29(6), 699-716.

Lamm, E., \& Meeks, M. D. (2009). Workplace fun: The moderating effects of generational differences. Employee Relations, $31(6), 613-631$.

Langer, W. (2017). How to assess the fit of multilevel logit models with Stata?. In German Stata Users' Group meetings 2017 (no. 05). Stata users group.

Levesque, M., \& Minniti, M. (2006). The effect of ageing on entrepreneurial behavior. Journal of Business Venturing, 21(2), 177-194.

Liden, R. C., Wayne, S. J., \& Sparrowe, R. T. (2000). An examination of the mediating role of psychological empowerment on the relations between the job, interpersonal relationships, and work outcomes. Journal of Applied Psychology, 85(3), 407.

Liñán, F., Santos, F. J., \& Fernández, J. (2011a). The influence of perceptions on potential entrepreneurs. International Entrepreneurship and Management Journal, 7(3), 373-390.

Liñán, F., Urbano, D., \& Guerrero, M. (2011b). Regional variations in entrepreneurial cognitions: Start-up intentions of university students in Spain. Entrepreneurship and Regional Development, 23(3-4), 187-215.

Liu, J., Zhu, Y., Serapio, M., \& Cavusgil, S. T. (2019). The new generation of millennial entrepreneurs: A review and call for research. International Business Review. https://doi. org/10.1016/j.ibusrev.2019.05.001.

Lyons, S. T., Schweitzer, L., Ng, E. S., \& Kuron, L. K. (2012). Comparing apples to apples: A qualitative investigation of career mobility patterns across four generations. Career Development International, 17(4), 333-357.

Lyons, S., \& Kuron, L. (2014). Generational differences in the workplace: A review of the evidence and directions for future research. Journal of Organizational Behavior, 35(S1), S139-S157.

Madanoglu, M., Memili, E., \& De Massis, A. (2019). Home-based family firms, spousal ownership and business exit: A transaction cost perspective. Small business economics, 116. https://doi.org/10.1007/s11187-018-00131-8.

McMullen, J. S., \& Shepherd, D. A. (2006). Entrepreneurial action and the role of uncertainty in the theory of entrepreneur. Academy Management Review, 31, 132-152.

Micelotta, E., Lounsbury, M., \& Greenwood, R. (2017). Pathways of institutional change: An integrative review and research agenda. Journal of Management, 0149206317699522.

Mickiewicz, T., Hart, M., Nyakudya, F., \& Theodorakopoulos, N. (2019). Ethnic pluralism, immigration and entrepreneurship. Regional Studies, 53(1), 80-94.

Millan, J. M., Congregado, E., Roman, C., Van Praag, M., \& van Stel, A. (2014). The value of an educated population for an individual's entrepreneurship success. Journal of Business Venturing, 29(5), 612-632.

Mize, T. D. (2019). Best practices for estimating, interpreting, and presenting nonlinear interaction effects. Sociological Science, 6, 81-117.

Monsen, E., Patzelt, H., \& Saxton, T. (2010). Beyond simple utility: Incentive design and trade-offs for corporate employee-entrepreneurs. Entrepreneurship Theory and Practice, 34(1), 105-130.

Monsen, E., Mahagaonkar, P., \& Dienes, C. (2012). Entrepreneurship in India: The question of occupational transition. Small Business Economics, 39(2), 359-382.

Müller S., Neck H. 2010. Generation impact: Student preferences to start social or traditional ventures. In United States Association for Small Business and Entrepreneurship. Conference Proceedings. United States Association for Small Business and Entrepreneurship; 157.

Narayanan, V. K., Yang, Y., \& Zahra, S. A. (2009). Corporate venturing and value creation: A review and proposed framework. Research Policy, 38(1), 58-76.

North, D. (1990). Institutions. Cambridge: Institutional Change and Economic Performance, Cambridge University Press.

Ouimet, P., \& Zarutskie, R. (2014). Who works for startups? The relation between firm age, employee age, and growth. Journal of Financial Economics, 112(3), 386-407.

Parker, S. C. (2011). Intrapreneurship or entrepreneurship? Journal of Business Venturing, 26(1), 19-34.

Parker, S. C. (2012). Theories of entrepreneurship, innovation and the business cycle. Journal of Economic Surveys, 26(3), 377-394.

Parry, E., \& Urwin, P. (2011). Generational differences in work values: A review of theory and evidence. International Journal of Management Reviews, 13(1), 79-96.

Pilkova, A., Holienka, M., \& Rehak, J. (2014). Senior entrepreneurship in the perspective of European entrepreneurial environment. Procedia Economics and Finance, 12, 523-532.

Porter, M. E. (1980). Competitive strategy. New York: The Free Press.

Prskawetz, A., Bloom, D. E., Lutz, W. 2008. Population ageing, human capital accumulation, and productivity growth. Population Council.

Raffiee, J., \& Feng, J. (2014). Should I quit my day job?: A hybrid path to entrepreneurship. Academy of Management Journal, 57(4), 936-963.

Ren, C. R., \& Guo, C. (2011). Middle Managers' strategic role in the corporate entrepreneurial process: Attention-based effects. Journal of Management, 37(6), 1586-1610.

Reynolds, P., Bosma, N., Autio, E., Hunt, S., De Bono, N., Servais, I., et al. (2005). Global entrepreneurship monitor: 
Data collection design and implementation 1998-2003. Small Business Economics, 24(3), 205-231.

Rigtering, J. P. C., \& Weitzel, U. (2013). Work context and employee behaviour as antecedents for intrapreneurship. International Entrepreneurship and Management Journal, 9(3), 337-360.

Roach, M., \& Sauermann, H. (2015a). Founder or joiner? The role of preferences and context in shaping different entrepreneurial interests. Management Science, 61(9), 2160-2184.

Roach, M., \& Sauermann, H. (2015b). Founders and joiners. Science, 348(6240), 1200-1201.

Rodriguez, R. O., Green, M. T., \& Ree, M. J. (2003). Leading generation X: Do the old rules apply? Journal of Leadership Organizational Studies, 9(4), 67-75.

Rosenzweig, M. R. (1990). Population growth and human capital investments: Theory and evidence. Journal of Political Economy, 98(5), S38-S70.

Roundy P. T. 2017. Small town" entrepreneurial ecosystems: Implications for developed and emerging economies. Journal of entrepreneurship in emerging economies, 2-2.

Ruiz, L. E., Amorós, J. E., Guerrero, M. 2019. Does gender matter on corporate entrepreneurship? A cross-country study. In academy of management proceedings (Vol. 2019, no. 1, p. 12908). Briarcliff manor, NY 10510: Academy of management.

Sahaym, A., Steensma, H., \& Barden, J. (2010). The influence of $\mathrm{R} \& \mathrm{D}$ investment on the use of corporate venture capital: An industry-level analysis. Journal of Business Venturing, 25, 376-388.

Scott, W. R. (1987). The adolescence of institutional theory. Administrative science quarterly, 493-511.

Scott, W. R. (2013). Institutions and organizations: Ideas, interests, and identities. Thousand Oaks, CA: Sage Publications.

Shane, S. (2011). The great recession's effect on entrepreneurship. Economic commentary $N^{\circ}$ 2001-04. Federal Reserve Bank of Cleveland: Cleveland.

Sharma, P., \& Chrisman, J. J. (1999). Toward a recognition of the definitional issues in the field of corporate entrepreneurship. Entrepreneurship: Theory \& Practice, 23(3), 11-27.

Shepherd, D. A., Mcmullen, J. S., \& Ocasio, W. (2017). Is that an opportunity? An attention model of top managers' opportunity beliefs for strategic action. Strategic Management Journal, 38(3), 626-644.

Shepherd D. A., Patzelt H. 2017. Researching the generation, refinement, and exploitation of potential opportunities. In trailblazing in entrepreneurship. Springer international publishing; 17-62.

Sieger, P., \& Monsen, E. (2015). Founder, academic, or employee? A nuanced study of career choice intentions. Journal of Small Business Management, 53(S1), 30-57.

Simon, M., Houghton, S. M., \& Aquino, K. (2000). Cognitive, biases, risk perception and venture formation: How individuals decide to start companies. Journal of Business Venturing, 15(2), 113-134.

Simpson, P. A., Greller, M. M., \& Stroh, L. K. (2002). Variations in human capital investment activity by age. Journal of Vocational Behavior, 61(1), 109-138.

Smola, K., \& Sutton, C. D. (2002). Generational differences: Revisiting generational work values for the new millennium. Journal of Organizational Behavior, 23(4), 363-382.

Srivastava, N., \& Agrawal, A. (2010). Factors supporting corporate entrepreneurship: An exploratory study. Vision, 14(3), 163-171.
StataCorp, L. P. (2013). Stata multilevel mixed-effects reference manual. College Station, TX: StataCorp LP.

Stevens, R. H. (2010). Managing human capital: How to use knowledge management to transfer knowledge in today's multi-generational workforce. International Business Research, 3(3), 77.

Stewart, J. S., Oliver, E. G., Cravens, K. S., \& Oishi, S. (2017). Managing millennials: Embracing generational differences. Business Horizons, 60(1), 45-54.

Stone, D. L., \& Deadrick, D. L. (2015). Challenges and opportunities affecting the future of human resource management. Human Resource Management Review, 25(2), 139-145.

Titus Jr., V., House, J. M., \& Covin, J. G. (2017). The influence of exploration on external corporate venturing activity. Journal of Management, 43(5), 1609-1630.

Twenge, J. M. (2010). A review of the empirical evidence on generational differences in work attitudes. Journal of Business and Psychology, 25(2), 201-210.

Twenge, J. M., Campbell, S. M., Hoffman, B. J., \& Lance, C. E. (2010). Generational differences in work values: Leisure and extrinsic values increasing, social and intrinsic values decreasing. Journal of Management, 36(5), 1117-1142.

Ucbasaran, D., Westhead, P., \& Wright, M. (2009). The extent and nature of opportunity identification by experienced entrepreneurs. Journal of Business Venturing, 24(2), 99-115.

Van Auken, H., Fry, F. L., \& Stephens, P. (2006). The influence of role models on entrepreneurial intentions. Journal of Developmental Entrepreneurship, 11(02), 157-167.

von Bonsdorff, M. E., Zhou, L., Wang, M., Vanhala, S., von Bonsdorff, M. B., \& Rantanen, T. (2018). Employee age and company performance: An integrated model of ageing and human resource management practices. Journal of Management, 44(8), 3124-3150.

Wanberg, C. R., Kanfer, R., Hamann, D. J., \& Zhang, Z. (2016). Age and reemployment success after job loss: An integrative model and meta-analysis. Psychological Bulletin, 142(4), 400.

Wong, M., Gardiner, E., Lang, W., \& Coulon, L. (2008). Generational differences in personality and motivation: Do they exist and what are the implications for the workplace? Journal of Managerial Psychology, 23(8), 878-890.

Wright, M., \& Hitt, M. A. (2017). Strategic entrepreneurship and the. SEJ: Development and Current Progress. Strategic Entrepreneurship Journal. https://doi.org/10.1002/sej.1255.

Yu, H. C., \& Miller, P. (2005). Leadership style: The X generation and baby boomers compared in different cultural contexts. Leadership \& Organization Development Journal, 26(1), 35-50.

Yusoff, A., Ahmad, N. H., \& Abdul Halim, H. (2019). Unravelling agropreneurship activities among Malaysian gen Y: Social institutional factors as enablers. International Journal of Entrepreneurial Behavior \& Research, 25(3), 457-479.

Zellweger, T., Sieger, P., \& Halter, F. (2011). Should I stay or should I go? Career choice intentions of students with family business background. Journal of Business Venturing, 26(5), 521-536.

Zhang, T., \& Acs, Z. (2018). Age and entrepreneurship: Nuances from entrepreneur types and generation effects. Small Business Economics. https://doi.org/10.1007/s11187-018-0079-4.

Publisher's note Springer Nature remains neutral with regard to jurisdictional claims in published maps and institutional affiliations. 